\title{
Serological Humoral Immunity Following Natural Infection of Children with High Burden Gastrointestinal Viruses
}

\author{
Mark R. Zweigart ${ }^{1}$, Sylvia Becker-Dreps ${ }^{1,2}{ }^{\text {, Filemón Bucardo }}{ }^{3}$, Fredman González ${ }^{3}$, Ralph S. Baric ${ }^{1, *(D)}$ \\ and Lisa $C$. Lindesmith $1, *$ (D) \\ 1 Department of Epidemiology, University of North Carolina, Chapel Hill, NC 27599, USA; \\ mrz@email.unc.edu (M.R.Z.); sbd@email.unc.edu (S.B.-D.) \\ 2 Department of Family Medicine, University of North Carolina, Chapel Hill, NC 27599, USA \\ 3 Department of Microbiology, National Autonomous University of Nicaragua, León 21000, Nicaragua; \\ fili_bucardo@med.unc.edu (F.B.); fredman.gonzalez@cm.unanleon.edu.ni (F.G.) \\ * Correspondence: rbaric@email.unc.edu (R.S.B.); lisal@unc.edu (L.C.L.); Tel.: +1-919-966-4689
}

check for updates

Citation: Zweigart, M.R.; Becker-Dreps, S.; Bucardo, F.; González, F.; Baric, R.S.; Lindesmith, L.C. Serological Humoral Immunity Following Natural Infection of Children with High Burden Gastrointestinal Viruses. Viruses 2021 13, 2033. https://doi.org/10.3390/ v13102033

Academic Editor: Susana Guix

Received: 10 September 2021

Accepted: 3 October 2021

Published: 9 October 2021

Publisher's Note: MDPI stays neutral with regard to jurisdictional claims in published maps and institutional affiliations.

Copyright: (c) 2021 by the authors. Licensee MDPI, Basel, Switzerland. This article is an open access article distributed under the terms and conditions of the Creative Commons Attribution (CC BY) license (https:/ / creativecommons.org/licenses/by/ $4.0 /)$.

\begin{abstract}
Acute gastroenteritis (AGE) is a major cause of morbidity and mortality worldwide, resulting in an estimated 440,571 deaths of children under age 5 annually. Rotavirus, norovirus, and sapovirus are leading causes of childhood AGE. A successful rotavirus vaccine has reduced rotavirus hospitalizations by more than $50 \%$. Using rotavirus as a guide, elucidating the determinants, breath, and duration of serological antibody immunity to AGE viruses, as well as host genetic factors that define susceptibility is essential for informing development of future vaccines and improving current vaccine candidates. Here, we summarize the current knowledge of disease burden and serological antibody immunity following natural infection to inform further vaccine development for these three high-burden viruses.
\end{abstract}

Keywords: rotavirus; norovirus; sapovirus; immunity; Caliciviridae; gastroenteritis; diarrhea; antibody; correlate of protection; histo-blood group antigen

\section{Introduction}

Rotavirus, norovirus, and sapovirus are nonenveloped RNA viruses that together cause a high proportion of the childhood gastroenteritis burden. In the multi-site Malnutrition and Enteric Disease Study (MAL-ED) birth cohort study, these three pathogens occupied three of the four top rankings of pathogens with the highest attributable incidence of diarrhea in children under 12 months of age [1]. A true success story in addressing the burden of childhood gastroenteritis has been the development and global roll-out of oral rotavirus vaccines. Despite somewhat lower vaccine effectiveness in low- and middle- income countries (LMIC), countries that added rotavirus vaccines to their national immunization schedules experienced a median reduction of 59\% (IQR, 46-74) in rotavirus hospitalizations and a median reduction of 36\% (IQR, 28-46) in all-cause gastroenteritis mortality [2]. While norovirus vaccines have reached phase II trials in children [3,4], to date, there are no licensed vaccines available against either of the high-burden caliciviruses, norovirus or sapovirus (Figure 1).

Due to their important contribution to gastroenteritis burden, elucidating the development of immunity to these three viruses is needed to understand patterns of susceptibility in populations and guide the development of future vaccines. Seminal birth cohort studies of rotavirus conducted in the 1990's broadened our understanding of the development of natural immunity and guided rotavirus vaccine development [5]. Understanding protective immunity to rotavirus provides a template to guide future research on norovirus and sapovirus. However, a significant challenge to understanding immunity to caliciviruses is the inability to easily grow these viruses in cell culture to produce viral antigens and perform infectivity studies. Instead, for norovirus, adult human challenge studies have 
played a pivotal role in understanding immunity, but may not reflect immunity in naïve infants, who suffer the greatest burden of disease. A comprehensive understanding of sapovirus immunity remains in its infancy, representing a clear and present priority for the development of vaccines.

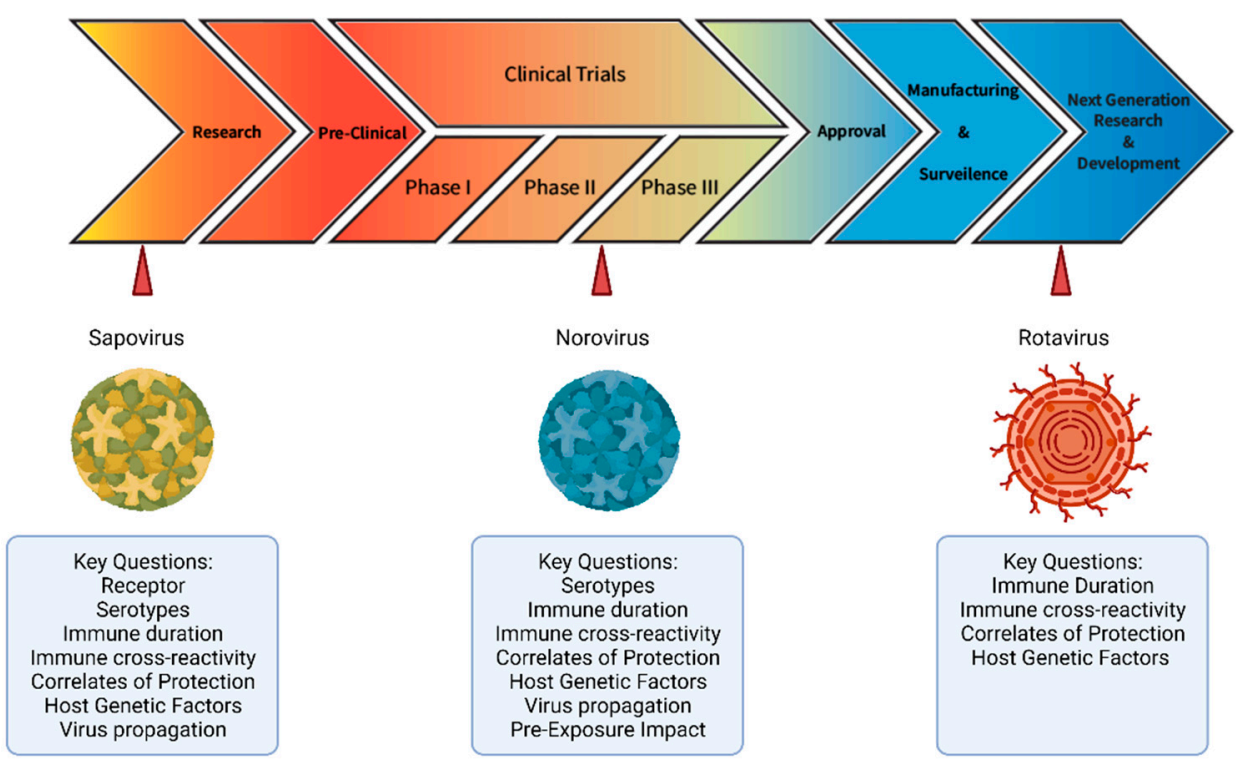

Figure 1. Graphical representation of current stages of research and development for sapovirus, norovirus, and rotavirus vaccines. Created with Adobe Illustrator and BioRender.com (accessed on 5 October 2021).

New data on host genetic susceptibility is further shaping our understanding of protection against rotavirus and norovirus. Histo-blood group antigens (HBGA) may mediate rotavirus and norovirus cellular attachment, and host HBGA phenotypes affect susceptibility to rotavirus and norovirus on a genotype-specific basis [6,7]. These host factors impact vaccine effectiveness which also help explain genotype distributions in populations [8,9].

The purpose of this review is to share recent knowledge and important gaps in the field on humoral immunity to rotavirus, norovirus, and sapovirus.

\section{Rotavirus}

\subsection{Rotavirus Structure and Antigenic Characteristics}

Rotavirus is an icosahedral triple-layered non-enveloped virus measuring $100 \mathrm{~nm}$ in diameter which contains 11 segments of double stranded RNA that encode six structural (VP1, VP2, VP3, VP4, VP6, and VP7) and six nonstructural proteins (NSP1 to NSP6) [10]. The middle layer is formed by VP6, a highly immunogenic protein, that elicits groupspecific antibodies and defines serogroups (A to J) [11]. The outer layer is formed by VP7, which is also highly immunogenic and defines G (glycoprotein) genotypes within serogroups $[12,13]$. VP4 is a spike protein inserted into the VP7 protein, is highly immunogenic and defines the P (protease-sensitive) genotypes [12,13]. During infection, VP4 is cleaved into VP5* and VP8*; VP8* then functions as a ligand for cell attachment [14].

VP7 and VP4 are highly diverse genetically. To date, $41 \mathrm{G}$ and $57 \mathrm{P}$ genotypes have been recognized to infect human and animals by the Rotavirus Classification Working Group. However, only 4 G genotypes (G1, G2, G3 and G4) mainly in combination with $2 \mathrm{P}$ genotypes ( $\mathrm{P}[4]$ and $\mathrm{P}[8]$ ) are globally prevalent in human populations, each of them showing fluctuations in incidence over time. The patterns of genotype variability over time suggests that genotype-specific immunity reduces transmission and disease burden, but sterilizing immunity is never fully achieved in most individuals. New G genotypes, such as G9 and G12 have emerged and become more common $[15,16]$. Moreover, animal- 
derived rotaviruses have emerged regionally (for example, porcine-like G5, bovine-like G8 and equine-like G3) and can spread globally [17-27]. The cross-species movement of animal derived rotavirus into humans may be due to co-infections with human and animal rotavirus strains, giving rise to reassortant strains which cannot be contained by herd immunity. A common observation is that animal-reassortant viruses retain the human $\mathrm{P}$ genotype, such as $\mathrm{P}[8]$.

\subsection{Rotavirus Pathogenesis}

Rotavirus infections cause non-bloody watery diarrhea, vomiting of short duration, and fever, and are associated with a limited inflammatory response [28,29]. Rotavirus infects the mature enterocytes in the mid and upper part of the villi of the small intestine [29]. Rotavirus-induced diarrhea is considered osmotic and non-inflammatory with diarrhea most likely due to extracellular accumulation of solutes and malabsorption as a result of enterocyte damage or death; or decreased epithelial absorptive function [29]. Another proposed mechanism is secretory diarrhea due to the effects of the viral enterotoxin, NSP4, on activation of the enteric nervous system. Rotavirus can exert effects on the central nervous system through nerve gut-brain communication, via the release of mediators, such as the rotavirus enterotoxin NSP4, which stimulates neighboring enterochromaffin cells in the intestine to release serotonin and activate both enteric neurons and vagal afferents to the brain [30]. There is evidence that the serotonin (5-HT3) receptor is involved in rotavirus-induced diarrhea by promoting intestinal motility [31] but not increased permeability [32]. There is also evidence of extra-intestinal rotavirus infection with antigenemia, and viremia commonly detected in hospitalized children within 10 days after onset of symptoms [33-37].

\subsection{Mechanisms of Protection against Rotavirus Infection and Disease}

There are two proposed mechanisms of protection against rotavirus infection. The first suggests that the protection is due to neutralizing antibodies that recognize serotypespecific epitopes on VP4 or VP7 proteins that block virus infection and entry [38]. The second proposes that protection is due to other effectors like non-neutralizing antibodies (Fc mediated is yet to be reported) and possibly T-cells (CD8 and/or CD4) [39-41]. Other effectors may include antibodies that recognize VP6, NSP4 or products of interferon-inducible genes like viperin [42-47]. For instance, immune responses against VP6, mediated by IgA, have been shown to inhibit viral replication in vitro and in vivo, and VP6 neutralization seems to be intracellular [45,46]. In addition, systemic and intestinal antibody responses to NSP4 enterotoxin have been documented in children and gnotobiotic pigs [42-44]. Regarding cellular protection, rotavirus T-cell studies in children have shown that rising antibody levels are accompanied by T-cell responses, but this cellular response is transient and disappears within one year [48-50]. These observations have led to the suggestion that rotavirus protection early in life is mediated by neutralizing antibodies and that serial infections may be needed for the development of stable memory T-cell populations [48]. Host genetics are another important factor in the protection against rotavirus. "Non-secretor" individuals do not express the $\mathrm{H}$ type- 1 histo-blood group antigen (HBGAs) on the intestinal epithelium, which seems to be required for cell attachment by the common rotavirus genotypes, $\mathrm{P}[8]$ and $\mathrm{P}[4]$ [51]. Several other factors, such as breastfeeding, intestinal microbiome composition, environmental enteropathy, and nutritional status have been suggested to either contribute to or impede immune protection against rotavirus acute gastroenteritis [52-59].

\subsection{Host Genetics and Health Outcomes}

HBGAs are a family of complex carbohydrates classified by terminal glycosylation patterns found in intestinal and other mucosa [6]. Innate susceptibility to rotavirus and human norovirus is regulated by polymorphisms in the genes that encode alpha 1,2 fructosyltransferase 2 (FUT2) (secretor enzyme) and Lewis enzyme (FUT3), and glycosyltransferases A and $\mathrm{B}$ [60-63]. These enzymes regulate glycosylation, starting at the precursor to $\mathrm{H}_{1}$. Secre- 
tor enzyme produces $\mathrm{H}_{1}$, which can be further modified by Lewis enzyme to form Lewis $b$ (Leb). A and/or B antigens can be added to $\mathrm{H}_{1}$ in addition to Leb. Non-secretors (FUT2 negative) can only express a very limited assortment of HBGAs in mucosal secretions. Structural studies on the interaction between the rotavirus ligand VP8* and histo-blood group antigens (HBGAs) show a conserved binding site on $\mathrm{P}[14]$ that specifically interacts with A-type HBGAs, suggesting that rotavirus pathogenesis is influenced by genetically controlled expression of different HBGAs in human populations [64]. Building upon these early structural studies, a saliva binding study showed that the VP8* of the P[4] and $\mathrm{P}[8]$ genotypes bind to saliva containing the Lewis B and secretor HBGAs, while the $\mathrm{P}[6]$ genotype was shown to bind to the secretor antigen only. These observations were later replicated using synthetic HBGAs [65]. A more recent study provided structural evidence for the interactions of the $\mathrm{P}$ [8] genotype with the secretor HBGA precursor, but binding experiments did not support interactions with Lewis A or B HBGAs [7]. Further structural studies proposed the hypothesis that evolution of genogroup P[II] RV (P[8], $\mathrm{P}[4]$ and $\mathrm{P}[6])$ progressed from animals to humans under the selection of type 1 HBGAs guided by stepwise host synthesis of type $1 \mathrm{ABH}$ and Lewis HBGAs [66].These laboratory observations have been supported by epidemiological studies showing that $\mathrm{P}[8]$ and $\mathrm{P}[4]$ genotypes infect Lewis B secretor children preferentially and P[6] infects Lewis-negative children preferentially, irrespective of the secretor phenotype [6,67-70]. The rotavirus P[6] genotype is more prevalent in sub-Saharan African and South-East Asian countries than in other populations, coinciding with a higher proportion of Lewis-negative phenotypes, reaching up to $30 \%$ of this population $[60,68,71,72]$. $\mathrm{P}[6]$ is also associated with neonatal infection and the structural basis for the age-restricted tropism have been reported for some P[6] strains. Authors suggest that this finding may be explained by the abundance of regulated unbranched glycans in the neonatal gut, that decline over time [73]. P[6] rotavirus is also found to circulate in pigs and there is evidence of interspecies transmission [74-78]. Human and porcine HBGAs share homology and type-A and H type 1 HBGAs are the most prevalent in pigs $[79,80]$. These similarities could form the basis for a mechanism of zoonotic and interspecies transmission of rotaviruses [79]. Studies examining the association between antibody response and HBGAs profiles have shown significantly higher IgG, IgA, and neutralizing antibody titers to rotavirus in secretor adults as compared to non-secretors [81]. Moreover, following rotavirus vaccination of children, IgA response and vaccine strain shedding are associated with secretor status [9,80,82-84].

\subsection{Correlates of Rotavirus Immunity and Protection in Children}

A central goal of vaccine research and the study of natural history of viral infections is to identify vaccine induced or naturally induced immune responses that predict protection from infection or disease, (Table 1). Among the predictors of protection from rotavirus infection and disease the most recognized are serum rotavirus IgA $(>1: 800)$ and VP7 specific IgA $(>1: 200)[85,86]$, followed by serum rotavirus IgG $(>1: 6400)$ and VP7 specific $\operatorname{IgG}(>1: 800)$, respectively [86]. Fecal IgA, antibody secreting cell (ASC), rotavirus CD4+, rotavirus specific or neutralizing antibodies that recognize NSP4, VP6, VP4, VP7, and also epitope-specific neutralizing antibodies to VP7 have been also studied [13,87]. Sterilizing immunity could not be induced by natural rotavirus infection or vaccination due to antigenic drift and shift caused by the error-prone viral RNA polymerase, and also due to other evolutionary characteristics of rotavirus like gene reassortment, gene recombination and interspecies transmission [88]. Historic studies in a gnotobiotic pig model of rotavirus infections have shown that protective immunity against diarrhea depends on the production of IgA and IgG antibody-secreting cells and memory B cell responses at the site of viral replication in the ileum; IgA memory B-cells decline substantially in about 3 months after infection [89]. Studies of natural rotavirus infections in children showed a similar positive association between $\operatorname{IgA}$ and $\operatorname{IgG}$ antibodies and protective immunity against rotavirus infection and diarrhea, but after adjusting for age, the effect was only partial [90]. Following immunization, anti-rotavirus IgA Geometric Mean Concentration (GMC) was 
associated with a decline in vaccine efficacy. Efficacy during the first 2 years of life was significantly lower in countries with vaccine-elicited IgA GMC < $90(44 \% ; 95 \%$ confidence interval [CI], 30-55) compared to countries with GMC > 90 (85\%; 95\% CI, 82-88) [91]. NSP4-specific antibodies may be important in protecting against clinical symptoms of rotavirus infection $[42,43,92]$. In children with rotavirus gastroenteritis and in animal models, NSP4 induces humoral immune responses with modest IgG seroconversion rates $(54-70 \%)$ and IgA being barely or not detected at all [42,44,93-95]. The titers of NSP4 specific IgG antibody have been found to be transient, increasing with age, peaking between 12-23 months of age and dropping to minimal levels afterwards [96]. A significant proportion of children who did not develop diarrhea associated with rotavirus infection had antibodies to NSP4 in acute-phase serum [44]. There is evidence that humans can circumvent the extensive serotype diversity of circulating rotavirus strains by generating frequent heterotypic neutralizing antibody responses to VP7, VP8* , and most often, to VP5* after natural infection [97]. Further research is warranted to understand whether VP6 IgG contributes to protection [37].

\subsection{Impact of Rotavirus Vaccination on Disease Burden in Children}

Current rotavirus vaccines have been available since 2006 and the World Health Organization (WHO) recommended universal infant rotavirus vaccination in 2009 [2]. As of 2020 , about $70 \%, 60 \%$ and $45 \%$ of the African, American, and European countries have introduced these vaccines in their national immunization schedules. Before vaccine introduction, it was estimated that rotavirus accounted for 527,000 deaths annually or $29 \%$ of all deaths due to diarrhea among children $<5$ years of age, with the majority of the fatal cases occurring in LMIC countries [98]. In contrast, in 2016, the fatalities due to rotavirus decreased to 128,500 among children $<5$ years throughout the world, with 104,733 deaths occurring in sub-Saharan Africa [99]. Data from the WHO-coordinated Global Rotavirus Surveillance Network reported a $40 \%$ relative decline in rotavirus positive specimens among children $<5$ years old hospitalized for diarrhea [100]. Among children $<5$ years old, there was a median reduction of 59\% (IQR, 46-74) in rotavirus hospitalizations, 36\% (IQR, 23-47) in acute gastroenteritis hospitalizations, and 36\% (IQR, 28-46) in mortality due to all-cause acute gastroenteritis [2]. Current and new licensed rotavirus vaccines, contain live attenuated strains that are given orally to children very early in life to induce either heterotypic or homotypic responses [101]. RotaTeq (G1-4/P[8]) and Rotasiil (G1-4 and G9) contain reassortant strains with a bovine rotavirus backbone and VP4 and VP7 from human origin, based on the concept of genotype-specific protection. In contrast, Rotarix (G1P[8]) and Rotavac (G9P[11]) consist of attenuated human RV strains and are based on the concept that one genotype induces heterotypic protection [102].

\subsection{Conclusions and Next Steps}

Globally prevalent and emerging rotavirus strains retain the ligand VP4 specificity (P[8] and P[4]) while changing the outer layer of VP7 (G1-4, G9, G12). The introduction of rotavirus vaccines against severe gastroenteritis has proven to be highly effective, more likely due to induction of mucosal IgA responses. Emerging observations suggest that immune response to rotavirus vaccines is dependent on host genetic factors such as the Lewis and secretor phenotypes. Efficacy studies examining these factors may inform the improvement of rotavirus vaccines. Vaccine developers might improve their vaccine design based on what is learned from observational and mechanistic studies on host susceptibility.

\section{Norovirus}

\subsection{Norovirus Burden of Disease}

Human norovirus is the leading cause of acute viral gastroenteritis, potentially accounting for up to $1 / 5$ th of all gastroenteritis cases worldwide. More than 200,000 children per year die from complications of human norovirus infection [103]. Children between 6 months and 5 years of age are at greatest risk of death [104]. Norovirus disease burden 
is similar to that of rotavirus before the development and implementation of rotavirus vaccines [2]. The economic costs of norovirus in the United States alone is estimated to exceed 10 billion dollars per year [105]. Symptoms common among all age groups include diarrhea, vomiting, nausea, and stomach pain; however, children under 5 years and adults over 65 years are at greater risk of severe disease [106-108]. Symptoms begin $12-48 \mathrm{~h}$ after initial exposure with a recovery within 2-5 days in acute cases in adult immune-competent individuals [109]. Infection may persist for longer in young children [110]. Secretor positive children with norovirus AGE present more severe symptoms than children with non-norovirus AGE [111-114]. Vomiting is a primary symptom in children seeking medical care for human norovirus AGE [115], sometimes with intensities indistinguishable from rotavirus infections.

\subsection{Virus Background}

Human norovirus is a calicivirus, with 3 open reading frames on a positive sense RNA genome of approximately 7.5 kilobases. ORF 1 encodes the viral replication machinery. ORFs 2 and 3 encode the major (VP1) and minor (VP2) capsid proteins. The viral capsid is composed of 90 dimers of the major capsid protein. The capsid protein is divided into functional domains; the interior shell and protruding domain that extends away from the shell surface [116]. Ligand binding and strain primary antigenic determinant for human norovirus comprise the most-exterior region of the protruding domain, the P2 subdomain [117-119]. Human norovirus is genetically and antigenically diverse. To date, there are 10 genogroups $(\mathrm{G})$, with GI and GII being the primary causes of disease in humans [120,121]. GI is comprised of 9 genotypes and GII is comprised of 27 genotypes [121]. GII strains account for $\sim 90 \%$ of infections and occur earlier in life than GI infections [122,123]. Infection follows a fecal-oral route, with infection possible with small amounts of virion exposure [124-127]. Once infected, children may shed virus for weeks post-infection [128]. Human norovirus is highly transmissible, especially in enclosed locations with a high density of people $[103,129]$. Highest mortality rates are recorded in long-term care/retirement faculties for adults and LMIC for children [130,131].

Little is known about in vivo replication of human norovirus, beyond infection of enterocytes in the small intestine. In vitro, infection of intestinal epithelial cells is facilitated by bile and ceramide [132]. Human norovirus capsid domains bind to select HBGAs in strain-specific patterns, determining genetic susceptibility of infection [60-62]. GII.4 variants are characterized by broad HBGA binding patterns and this breadth of ligand binding contributes to the global dominance of these stains $[133,134]$. Secretor-negative individuals are mostly protected from some genotypes that require $\mathrm{H}$ or $\mathrm{AB}$ antigens, such as GI.1 and GII.4 strains [8,60-62]. Exceptions to innate susceptibility for secretornegative people have been documented for GI.2, GI.3, GII.1, GII.2, GII.3, GII.6, GII.7, GII.17, and rarely GII.4 $[60,135,136]$, indicating genetic resistance is highly protective against human norovirus genotypes but does not provide complete protection from infection from all genotypes.

Young children are most at risk of infection and severe disease. Peak infection rates occur during the first two years of life with studies reporting $>30$ infecting genotypes in children under 18 years old and 22 genotypes in children $\leq 5$ years old $[122,123,137]$. Globally, GII strains account for $>90 \%$ of infections [122,123]. Within GII, GII.4 variants are responsible for $40->95 \%$ of infections in children $[107,137,138]$. GII.4 infections are most frequently the first infecting strain and are more likely to have severe symptoms than non-GII.4 infections $[107,112,113,139]$.

Non-GII.4 genotypes, peak and ebb in prevalence [113,123,140]. GII.3, GII.6, GII.2, GII.12 and GII.17 are frequently detected [123,141-143]. GI.3 is the most frequently detected GI genotype [122,123]. Infecting strains are classified by the capsid sequence. Capsid genes commonly circulate with interchangeable polymerase types, as recombinant viruses [144]. The difference in virulence between recombinant viruses compared to non-recombinant viruses is under investigation but hampered by the lack of tools for 
evaluation [141,145-148]. Co-infection with other AGE viruses, bacteria and parasites are also common and understudied [137,149-151].

\subsection{Correlates of Protection}

Antigenicity and immunogenicity studies have focused on the major capsid protein as the primary target of antibody responses, although antibodies to non-structural proteins have been identified [152]. Serological evidence of human norovirus exposure is ubiquitous in children across income brackets. Both reactive $\operatorname{IgG}$ and antibody that blocks ligand binding in a surrogate neutralization assay (blockade antibody) responses have been detected in the sera of children $<6$ months of age. Antibodies present before 6 months of age are likely maternally derived and provide some degree of protection from infection in early infancy [104,153-156]. By 12 months of age, child-derived serum antibody titers are present $[104,155,157]$. By age 3 , most children have experienced primary human norovirus infection, and seropositivity may reach $>90 \%$ in some populations $[48,153,157,158]$. Generally, GI antibodies are less frequently detected and are detected at an older age than GII antibodies $[48,156,157,159]$. Serum antibodies to GII.4 strains are the most detected antibodies, aligning with global strain circulation patterns [160]. Virus exposure and antibody titers remain high into older adulthood [106,161,162].

Characterizing human norovirus serotypes would provide key information for designing rational vaccine platforms that provide cross-protection and for determining correlates of protection for bridging vaccine studies. Studies indicate there is little cross-genogroup protection in humans $[154,160,163-165]$. Studies have found few examples of repeat genotype infections but multiple infections within a genogroup are common, suggesting some genotypes may correspond to serotypes, at least in young children with limited exposure histories [165-169].

Surveying for reactive antibody is useful for prevalence studies but extrapolation of findings for human norovirus is complex. Increases in homotypic serum antibody titers is highly correlated with detection of viral strains in stool and determining infection $[61,62,170]$. DNA sequencing of PCR products generated from fecal extracted RNA can accurately determine an infecting viral strain but the extensive and expanding diversity of human norovirus genotypes limits the ability to screen sera for reactivity to matched VLP in many cases. Since infection and vaccination induce antibodies to non-neutralizing epitopes conserved within and across GI and GII genotypes [164,171,172] interpretation of antibody binding data alone is not definitive for determining genotype infection.

Antibodies induced by infection are likely protective. Children with GII.4 antibodies are less likely to get a GII.4 infection than children without GII.4 antibodies [153,173]. Treatment of infection in immunocompromised individuals with oral immunoglobulin preparations reduced symptoms/infection in some cases but not others, suggesting strainmatched lots of immunoglobulin may be needed for efficacy [174-178]. Little is known about functions of different antibody isotypes in protection from infection or about antibodies to viral components outside the major capsid protein. In adults, salivary and serum IgA, but not serum IgG, correlate with protection from infection/symptoms $[61,179,180]$.

Antibody able to blockade VLP binding to carbohydrate ligand is the most often demonstrated correlate of protection and is applied widely in evaluating infection and vaccine responses [179,181-184]. The "blockade assay", is a surrogate assay for measuring virus-neutralizing antibody that disrupts virus cellular docking mechanisms and primarily target epitopes in the surface-exposed P2 domain [119,164,171,185]. All tested blockade antibodies also neutralize virus in an in vitro cell culture model, validating the surrogate assay $[171,172,186,187]$. Unlike reactive antibodies, blockade antibodies are highly genotype specific $[164,169,171,187]$, and readily discriminate between variants of GII.4 strains $[164,171,188,189]$. This high specificity contributes to the usefulness of the blockade assay as a correlate of protection. Elevated pre-challenge titers of blockade antibody correlate with reduced infection and/or symptoms post-infection in controlled human challenge studies in adults $[179,182,190,191]$. Reconstitution of variant-specific blockade 
antibody correlated with resolution of diarrhea in an immune compromised patient [192]. IgA and IgG serum antibodies and recombinant monoclonal antibodies have blockade potency $[164,172,178,187,193-195]$. The relationship between these serum antibodies and mucosal antibodies is under explored, but serum IgA, salivary IgA and blockade antibody titer correlate with each other $[195,196]$. One study, demonstrated IgA and IgG isolated from saliva had blockade activity, supporting common functionality between antibodies of the systemic and mucosal compartments [195]. Future studies focusing on mucosal immune compartments may strengthen the association of blockade antibody and protection and further define serotypes of human noroviruses.

Few investigations of blockade antibody have been described for children, identifying a critical knowledge gap needed to inform vaccine development and evaluation. From limited studies of children $<6$ months of age, maternal antibody includes blockade antibodies [104] and infection induces development of strain-specific blockade antibodies accompanied with increased serum antibody avidity [104,169]. In two studies of children less than 2 years old infected with GII.4.2009 New Orleans, blockade antibodies to GII.4.2009 New Orleans were low in acute sera and increased $>4$-fold in convalescent samples, indicating very young children generate potentially protective antibody responses to infection $[173,197]$. Blockade antibody cross-reacted, although to a lower titer, with the closely related variant GII.4.2012 Sydney but not the distantly related variant GII.4.1999 US95/96, supporting findings with adult sera demonstrating antibody-mediated immune escape by evolved GII.4 variants [133,198,199].

Although infected and vaccinated adults have cross-genotype blockade antibody responses that persist for at least one month $[163,181,193,200]$, no cross-genotype blockade antibody responses have yet been characterized in children. It is unclear how many infections are needed to develop blockade antibody titer, what titer is needed to provide protection and how long these titers persist after infection. These questions would best be answered through birth cohort studies with continuous collection of stool and sera accompanied by RT-qPCR monitoring of both symptomatic and asymptomatic human norovirus infection. Blockade antibody assays with infection-matched virus-like particles as antigens would allow for precise measurement of development and duration of immunity and evaluation of cross-protection, key information for designing effective vaccines and metrics for measuring vaccine outcomes.

\subsection{Vaccine Development}

Two human norovirus vaccine candidates are in clinical trials in heathy adults. Both systems use VP1 based VLPs as immunogen. The Vaxart vaccine platform uses a VP1expressing adenovirus vector along with a double stranded RNA adjuvant that delivers the immunogen at the gut mucosa via an oral tablet [183]. In a preliminary two dose study, a monovalent GI.1 vaccine was both safe and immunogenic and induced GI.1-specific blockade antibody titers two-fold in $61 \%$ of low dose participants and $78 \%$ of high dose participants at day 28 [183]. Further, VP1-specific IgA memory B cells and plasmablasts, and IgA+ plasmablasts expressing mucosal homing receptors were elevated at seven days following a single dose of vaccine [183]. Follow up study of a bivalent GI.I/GII.4 vaccine candidate using the same platform is currently in phase 1B trials (NCT03897309). Challenge studies to test the efficacy of either Vaxart vaccine candidate have yet to be conducted. The Takeda bivalent VLP vaccine comprises an intramuscular injection of purified VLP from VP1 of both GI.1 and GII.4 with $\mathrm{Al}(\mathrm{OH})_{3}$ adjuvant $[181,191,201]$. Immunization resulted in rapid, broad blockade antibody responses to the vaccine components, other GI and GII strains and two GII.4 strains not widely circulating, providing the first piece of evidence that vaccination may provide cross-protection across genotypes and GII.4 variants [181]. A 15/50 $\mu \mathrm{g}$ ratio of GI.1 to GII.4 VLP dose resulted in a balanced response to both VLP antigens [202]. Pan-immunoglobulin, IgA, and HBGA blockade antibodies remained elevated at day 365 following one dose [203]. Most importantly, the bivalent VLP vaccine demonstrated $68 \%$ efficacy for moderate/severe norovirus acute gastroenteritis caused by 
any human norovirus in a field study [201]. Immunity at the mucosal site of infection likely determines the outcome of virus challenge. However, correlates of protection at the gut mucosa are unknown, complicating predicting the success of any human norovirus vaccine.

There are significant challenges to the development of a human norovirus vaccine, primarily centered around the antigenic diversity among strains infecting young children. Globally, for the past 30 years, GII.4 variants have been the leading cause of human norovirus infection, in all age groups. Success of these viruses is facilitated by binding to a broad selection of HBGAs resulting in large susceptible populations and antigenic drift in neutralizing epitopes resulting in escape from herd immunity $[119,133,189,204]$. GII.4 evolution is the key obstacle to vaccination. To counter antigenic diversity and viral evolution, a multivalent immunogen platform is most likely to provide antibody breadth and protection, as antibodies to epitopes conserved across genogroups or genotypes provide little ligand blockade or neutralizing potential $[205,206]$. The human norovirus vaccine clinical trials have exclusively studied adults and antibody responses were predominantly memory recall responses $[171,181,202,207,208]$. Children are the primary target population for human norovirus vaccination, since they bear the highest burden of norovirus disease and vaccination of children would decrease disease in older adults as well [209]. Vaccines in the very young will have to elicit breadth across antigenically diverse viruses. This goal will potentially be confounded by limited exposure histories in infants. How the current vaccine candidates will perform under these conditions is unknown as is whether the mucosal/intramuscular immunogen delivery effects immune responses or protection. These questions should be a high priority for study.

\section{Sapovirus}

\subsection{Burden of Disease across the Ages and State of Vaccine Development}

Sapovirus is increasingly recognized as an important cause of childhood diarrhea. The Malnutrition and Enteric Disease (MAL-ED) study, a multi-site birth cohort study of enteric infections in LMICs, found sapovirus to have the second highest attributable incidence for diarrhea among all enteric pathogens studied in children under 24 months of age [1].

Sharing clinical characteristics with closely-related noroviruses, common symptoms of sapovirus gastroenteritis include vomiting and diarrhea [210]. Farkas, et al. reported the seroprevalence of sapovirus (Mex340 strain) in children between 20 and 24 months of age involved in a birth cohort was greater than $90 \%$, showing the high incidence of infections in early childhood [211]. Also in young children, one study, found sapovirus to be s associated with lower cognitive scores [212]. In children in the US, sapovirus has been detected in $10 \%$ of cases seeking care for diarrhea [213].

Sapovirus is also responsible for gastroenteritis outbreaks including in nursing homes, highlighting, its contribution to the burden of gastroenteritis in older adults [214]. Finally, while sapovirus is primarily associated with acute gastroenteritis, it has also been detected in cases of chronic diarrhea among individuals with immunocompromising conditions [215-217]. Despite its importance to human health across the age spectrum, there have been little efforts made to develop vaccines against sapovirus.

\subsection{Virus Structure and Genetic Diversity}

Sapoviruses are non-enveloped, single-stranded, positive-sense RNA viruses. They form the genus sapovirus within the family Caliciviridae. The sapovirus genome consists of two open reading frames: ORF1 encodes the virus nonstructural proteins and major capsid protein, VP1, and ORF2 encodes VP2, the minor structural protein [218]. Sapoviruses have been divided into 19 genogroups, with viruses from four of these (GI, GII, GIV, and GV), including 18 genotypes are known to infect humans [219]. Of these genotypes, sapovirus GI.1 is the most frequently detected worldwide [220]. The cellular binding site of sapovirus is not known; unlike noroviruses, there is no evidence for an association between host HBGA expression and disease risk [221]. Until very recently, sapovirus could not be replicated in cell culture, presenting challenges for understanding immunity including 
limiting infectivity studies and the production of antigen needed to measure humoral immunity [222]. Recent advances in cell culture of sapovirus [222] provide optimism that a deeper understanding of sapovirus immunity may be possible in the near future once these methods have been further established.

\subsection{Health Outcomes/Host Population}

Sharing clinical disease characteristics with closely-related noroviruses, common symptoms of sapovirus gastroenteritis include vomiting and diarrhea, which typically resolve within one week [210]. A MAL-ED study of enteric infections in children in LMICs, found sapovirus to have the third highest attributable incidence for diarrhea of all enteric pathogens among children under 12 months of age, and the second highest attributable incidence among children between 12 and 24 months of age [1]. Further, a Bangladeshi study identified sapovirus as one of only two enteric pathogens associated with lower cognitive scores in children at 24 months of age [212]. In the US, sapovirus has also been detected in $10 \%$ of children under age 18 receiving care for diarrhea in both the inpatient and outpatient settings [213]. Sapovirus is also responsible for gastroenteritis outbreaks, including in day care centers [223,224], schools [223,225,226], hospitals, $[227,228]$ and nursing homes $[214,223,229,230]$. The fact that sapovirus was identified as the second most common cause of gastroenteritis outbreaks in nursing homes in the UK highlights its contribution to the burden of gastroenteritis in older adults [214]. Finally, while sapovirus is primarily associated with acute gastroenteritis, it has also been detected in cases of chronic diarrhea among individuals with immunocompromising conditions $[215,216]$.

\subsection{Immune Protection against Sapovirus}

Epidemiological data from the MAL-ED birth cohort show a modest reduction in the hazard of future sapovirus infections after a first infection [HR $=0.92(92 \% \mathrm{CI}, 0.82,1.03)]$, which decreases further after 2 or more infections [HR $=0.78(95 \% \mathrm{CI}, 0.69,0.88)]$ [231] The low protection following infection may reflect the genetic diversity within this viral genus. Little is currently known about determinants of humoral immunity to sapovirus and correlates of protection. Humoral immunity to sapovirus in acute and convalescent samples was first demonstrated by Chiba, et al., in 1979 using purified viruses from infected stool samples [232]. Early seroprevalence studies showed that seroprevalence increases with age, reaching the highest levels in late childhood that continues into adulthood, and falls in adults over 60 years of age [233]. This suggests that early life infections may provide durable humoral immunity that lasts until immunosenescence occurs in old age, and burden again increases $[214,233]$. Information on protection afforded by humoral immunity to sapovirus includes a study by Nakata, et al., who analyzed 41 paired sera from infants involved in a sapovirus outbreak using radio-immunoassays [233,234]. Among the 23 infants without preexisting antibody, 73\% developed clinical symptoms and showed increases in sapovirus-specific antibody titers. Among the 18 infants with preexisting antibody, only $17 \%$ became sick and all but 3 experienced increases in sapovirus-specific antibody titers. These data show that serum antibody correlated with protection against clinical disease and that boosting occurs upon re-infection. However, it is not known if serum antibody is the most important correlate of protection against sapovirus or whether it simply mirrors the antibody levels on the intestinal mucosa. As the small intestinal mucosa is the location of infection, it is presumed that fecal IgA antibodies are important to immune protection and that innate immune activation against viral infection is mediated through the interferon pathway [235]. Chronic sapovirus infections in individuals with immunodeficiencies show that clearance of infections depends on intact host immune responses [216,236].

There is also little known about the breadth of humoral immunity following sapovirus infection. Studies using baculovirus-expressed viral capsid proteins and hyperimmune antisera showed that sapoviruses differ antigenically from GI and GII noroviruses [237]. Studies with hyperimmune sera show that human sapovirus genogroups are antigenically 
distinct, as there is strong reactivity against VLPs of homologous sapoviruses, but little cross reactivity between genogroups [238]. Epidemiological studies provide additional insights on the breath of sapovirus immunity. In a Peruvian birth cohort it was found that repeat sapovirus infections do occur, but repeat infections with the same genotype are rare: over two years of surveillance; 59 of 82 children who experienced a sapovirus infection went on to have a repeat sapovirus infection, however only three repeat infections were of the same genotype $[239,240]$. These data suggest that first sapovirus infections provide immunity against homologous infections, but little protection against infections of different genogroups, and possibly different genotypes. Further, the low incidence of symptomatic sapovirus episodes in the first months of life in epidemiological studies supports early protection from maternal immunity $[210,239]$.

\subsection{Early Knowledge about Viral Epitopes}

Little is known about the viral structure and antigenic characteristics of sapovirus. Other caliciviruses have a conserved domain of VP1 capsid, while the structures and sequences of the $\mathrm{P}$ domain are variable. To date, structural approaches to characterize sapovirus have used chimeric VP1 capsids from vesivirus, a genus in the Caliciviridae family; these investigations helped to predict the $S$ and $P$ domains and have shown that elevated P-dimers could expose immunoreactive epitopes [241]. Unfortunately, to date there are no high resolution VLP structures that allow a detailed structural analysis of the sapovirus particle [242].

The use of immunoinformatic tools can help to uncover the antigenicity of sapovirus, Amin et al. predicted the 3D structure of the capsid protein of human sapovirus using a homology model; they were able to predict five conserved epitopes for T-cells that may also have binding affinity for B -cells [243]. However, the prediction was based on an atomic structure of a native calicivirus of the genus vesivirus that showed only $27 \%$ identity and $42 \%$ similarity with the target sapovirus sequence, so caution is warranted [243]. A better understanding of antigenic properties and identification of immunogenic epitopes would inform future vaccine development.

\subsection{What We Need to Move Forward with Better Understanding of Immunity}

Much can be learned from the fields of rotavirus and norovirus to advance our understanding of humoral immunity and correlates of protection against sapovirus. Information on natural boosting, re-infection, and antibody persistence in children is limited. Also, the role of animal sapovirus strains in causing clinical disease or immune boosting has not been established. There is optimism for the future success of vaccines due to the predominance of a single genotype, [244-246] lack of epidemic strains (such as norovirus GII.4), and evidence for durable immunity through adulthood. Finally, new tools are emerging to facilitate these investigations, including the use of VLPs for antigen production and recent developments in cell culture propagation techniques [222].

\section{Conclusions and Key Questions Moving Forward}

Acute gastroenteritis caused by viruses is one of the major causes of death worldwide. Effective vaccines coupled with other effective preventive measures (improved water quality and sanitation, breastfeeding and nutritional interventions) are needed to relieve this burden of illness on vulnerable populations, primarily young children. Duration and breadth of immunity provided by infection and vaccination and how these outcomes are impacted by pre-exposure history and host genetics are key questions of concern (Figure 1). Study of birth cohorts should be prioritized to answer these questions. These studies would also yield valuable virus challenge inoculum for additional controlled human challenge models for vaccine and therapeutics evaluation $[170,190]$. New tools for norovirus and sapovirus reagent development and the pathways paved through prior research on rotavirus and norovirus humoral immunity, will aid investigators to more 
quickly answer these questions and others to guide vaccine development, including number of doses, which antigens to choose and whether booster doses will be necessary.

Table 1. Serological Correlates of Protection.

\begin{tabular}{|c|c|c|c|c|}
\hline Virus & Correlate & Infection & Symptoms & Reference \\
\hline \multirow{5}{*}{ Rotavirus } & Rotavirus IgA and IgG in serum & $x$ & $x$ & {$[86,91,247]$} \\
\hline & Genotype specific IgA and IgG in serum & $x$ & $x$ & [85] \\
\hline & Rotavirus IgA in stools & $x$ & $x$ & {$[248,249]$} \\
\hline & VP6 serum and fecal IgA & $x$ & & {$[45,46,250]$} \\
\hline & NSP4 IgG & & $x$ & {$[42,93,94]$} \\
\hline \multirow{5}{*}{ Human Norovirus } & Salivary IgA & $x$ & $x$ & {$[61,180]$} \\
\hline & Memory IgG cells & & $X$ & {$[39,89]$} \\
\hline & Blockade $\mathrm{Ab}$ titer & $X$ & $x$ & {$[173,179,182,190]$} \\
\hline & Hemagglutination Inhibition titer & $x$ & $x$ & [251] \\
\hline & Serum IgA & $x$ & $X$ & [179] \\
\hline Sapovirus & Serum Ig & & $x$ & [234] \\
\hline
\end{tabular}

Author Contributions: Conceptualization: L.C.L., S.B.-D. and F.B. Writing all drafts: M.R.Z., F.B., S.B.-D., F.G., L.C.L. and R.S.B. Funding Acquisition and Supervision: R.S.B., S.B.-D. and F.B. All authors have read and agreed to the published version of the manuscript.

Funding: This research was funded by the National Institute of Allergy and Infectious Disease R01 AI148260 (RSB), R01AI127845 and K24AI141744 (SBD); Wellcome Trust [203268/Z/16/Z]; Fogarty International Center D43TW010923 (FG).

Institutional Review Board Statement: Not applicable.

Informed Consent Statement: Not applicable.

Acknowledgments: The authors wish to thank Michael L. Mallory, Paul D. Brewer-Jensen and Samantha R. May for critical review of the manuscript.

Conflicts of Interest: L.C.L. and R.S.B. hold patents on norovirus vaccine design and ongoing collaborations with VaxArt and Takeda Vaccines that are unrelated and do not pose conflicts of interest with this report. MRZ, FG, FB declare no conflicts of interest. SBD has an ongoing research collaboration with Takeda Vaccines that is unrelated and does not pose conflicts of interest with this report. The funders had no role in the design of the study; in the collection, analyses, or interpretation of data; in the writing of the manuscript, or in the decision to publish the results.

\section{References}

1. Platts-Mills, J.A.; Liu, J.; Rogawski, E.T.; Kabir, F.; Lertsethtakarn, P.; Siguas, M.; Khan, S.S.; Praharaj, I.; Murei, A.; Nshama, R.; et al. Use of quantitative molecular diagnostic methods to assess the aetiology, burden, and clinical characteristics of diarrhoea in children in low-resource settings: A reanalysis of the MAL-ED cohort study. Lancet Glob. Health 2018, 6, e1309-e1318. [CrossRef]

2. Burnett, E.; Parashar, U.D.; Tate, J.E. Global Impact of Rotavirus Vaccination on Diarrhea Hospitalizations and Deaths Among Children <5 Years Old: 2006-2019. J. Infect. Dis. 2020, 222, 1731-1739. [CrossRef]

3. Zhang, M.; Fu, M.; Hu, Q. Advances in Human Norovirus Vaccine Research. Vaccines 2021, 9, 732. [CrossRef] [PubMed]

4. Nordgren, J.; Sharma, S.; Bucardo, F.; Nasir, W.; Gunaydin, G.; Ouermi, D.; Nitiema, L.W.; Becker-Dreps, S.; Simpore, J.; Hammarstrom, L.; et al. Both Lewis and secretor status mediate susceptibility to rotavirus infections in a rotavirus genotypedependent manner. Clin. Infect. Dis. 2014, 59, 1567-1573. [CrossRef]

5. Velázquez, F.R.; Matson, D.O.; Calva, J.J.; Guerrero, L.; Morrow, A.L.; Carter-Campbell, S.; Glass, R.I.; Estes, M.K.; Pickering, L.K.; Ruiz-Palacios, G.M. Rotavirus infection in infants as protection against subsequent infections. N. Engl. J. Med. 1996, 335, 1022-1028. [CrossRef]

6. Ruvoën-Clouet, N.; Belliot, G.; Le Pendu, J. Noroviruses and histo-blood groups: The impact of common host genetic polymorphisms on virus transmission and evolution. Rev. Med. Virol. 2013, 23, 355-366. [CrossRef] 
7. Gozalbo-Rovira, R.; Ciges-Tomas, J.R.; Vila-Vicent, S.; Buesa, J.; Santiso-Bellon, C.; Monedero, V.; Yebra, M.J.; Marina, A.; Rodriguez-Diaz, J. Unraveling the role of the secretor antigen in human rotavirus attachment to histo-blood group antigens. PLoS Pathog. 2019, 15, e1007865. [CrossRef]

8. Reyes, Y.; González, F.; Gutierrez, L.; Blandon, P.; Centeno, E.; Zepeda, O.; Toval-Ruíz, C.; Lindesmith, L.C.; Baric, R.S.; Vielot, N.; et al. Secretor status strongly influences the incidence of symptomatic norovirus infection in a genotype-dependent manner in a Nicaraguan birth cohort. J. Infect. Dis. 2021, jiab316. [CrossRef]

9. Bucardo, F.; Reyes, Y.; Ronnelid, Y.; Gonzalez, F.; Sharma, S.; Svensson, L.; Nordgren, J. Histo-blood group antigens and rotavirus vaccine shedding in Nicaraguan infants. Sci. Rep. 2019, 9, 10764. [CrossRef] [PubMed]

10. Jayaram, H.; Estes, M.K.; Prasad, B.V. Emerging themes in rotavirus cell entry, genome organization, transcription and replication. Virus Res. 2004, 101, 67-81. [CrossRef] [PubMed]

11. Afchangi, A.; Jalilvand, S.; Mohajel, N.; Marashi, S.M.; Shoja, Z. Rotavirus VP6 as a potential vaccine candidate. Rev. Med. Virol. 2019, 29, e2027. [CrossRef]

12. Hoshino, Y.; Kapikian, A.Z. Rotavirus serotypes: Classification and importance in epidemiology, immunity, and vaccine development. J. Health Popul. Nutr. 2000, 18, 5-14.

13. Clarke, E.; Desselberger, U. Correlates of protection against human rotavirus disease and the factors influencing protection in low-income settings. Mucosal. Immunol. 2015, 8, 1-17. [CrossRef] [PubMed]

14. Arias, C.F.; Lopez, S. Rotavirus cell entry: Not so simple after all. Curr. Opin. Virol. 2021, 48, 42-48. [CrossRef] [PubMed]

15. Matthijnssens, J.; Heylen, E.; Zeller, M.; Rahman, M.; Lemey, P.; Van Ranst, M. Phylodynamic analyses of rotavirus genotypes G9 and G12 underscore their potential for swift global spread. Mol. Biol. Evol. 2010, 27, 2431-2436. [CrossRef] [PubMed]

16. Jain, S.; Vashistt, J.; Changotra, H. Rotaviruses: Is their surveillance needed? Vaccine 2014, 32, 3367-3378. [CrossRef]

17. Amit, L.N.; Mori, D.; John, J.L.; Chin, A.Z.; Mosiun, A.K.; Jeffree, M.S.; Ahmed, K. Emergence of equine-like G3 strains as the dominant rotavirus among children under five with diarrhea in Sabah, Malaysia during 2018-2019. PLoS ONE 2021, 16, e0254784. [CrossRef] [PubMed]

18. Bonura, F.; Banyai, K.; Mangiaracina, L.; Bonura, C.; Martella, V.; Giammanco, G.M.; De Grazia, S. Emergence in 2017-2019 of novel reassortant equine-like G3 rotavirus strains in Palermo, Sicily. Transbound. Emerg. Dis. 2021. [CrossRef]

19. Akane, Y.; Tsugawa, T.; Fujii, Y.; Honjo, S.; Kondo, K.; Nakata, S.; Fujibayashi, S.; Ohara, T.; Mori, T.; Higashidate, Y.; et al. Molecular and clinical characterization of the equine-like G3 rotavirus that caused the first outbreak in Japan, 2016. J. Gen. Virol. 2021, 102, 001548. [CrossRef]

20. Athiyyah, A.F.; Utsumi, T.; Wahyuni, R.M.; Dinana, Z.; Yamani, L.N.; Sudarmo, S.M.; Ranuh, R.G.; Darma, A.; Raharjo, D.; Matsui, C.; et al. Molecular Epidemiology and Clinical Features of Rotavirus Infection Among Pediatric Patients in East Java, Indonesia During 2015-2018: Dynamic Changes in Rotavirus Genotypes from Equine-Like G3 to Typical Human G1/G3. Front. Microbiol. 2019, 10, 940. [CrossRef]

21. Utsumi, T.; Wahyuni, R.M.; Doan, Y.H.; Dinana, Z.; Soegijanto, S.; Fujii, Y.; Yamani, L.N.; Matsui, C.; Deng, L.; Abe, T.; et al. Equine-like G3 rotavirus strains as predominant strains among children in Indonesia in 2015-2016. Infect. Genet. Evol. 2018, 61, 224-228. [CrossRef]

22. Pietsch, C.; Liebert, U.G. Molecular characterization of different equine-like G3 rotavirus strains from Germany. Infect. Genet. Evol. 2018, 57, 46-50. [CrossRef]

23. Guerra, S.F.S.; Soares, L.S.; Lobo, P.S.; Penha Junior, E.T.; Sousa Junior, E.C.; Bezerra, D.A.M.; Vaz, L.R.; Linhares, A.C.; Mascarenhas, J.D.P. Detection of a novel equine-like G3 rotavirus associated with acute gastroenteritis in Brazil. J. Gen. Virol. 2016, 97, 3131-3138. [CrossRef] [PubMed]

24. Doro, R.; Marton, S.; Bartokne, A.H.; Lengyel, G.; Agocs, Z.; Jakab, F.; Banyai, K. Equine-like G3 rotavirus in Hungary, 2015-Is it a novel intergenogroup reassortant pandemic strain? Acta Microbiol. Immunol. Hung. 2016, 63, 243-255. [CrossRef]

25. Hoa-Tran, T.N.; Nakagomi, T.; Vu, H.M.; Do, L.P.; Gauchan, P.; Agbemabiese, C.A.; Nguyen, T.T.; Nakagomi, O.; Thanh, N.T. Abrupt emergence and predominance in Vietnam of rotavirus A strains possessing a bovine-like G8 on a DS-1-like background. Arch. Virol. 2016, 161, 479-482. [CrossRef]

26. Jagannath, M.R.; Vethanayagam, R.R.; Reddy, B.S.; Raman, S.; Rao, C.D. Characterization of human symptomatic rotavirus isolates MP409 and MP480 having 'long' RNA electropherotype and subgroup I specificity, highly related to the P6[1], G8 type bovine rotavirus A5, from Mysore, India. Arch. Virol. 2000, 145, 1339-1357. [CrossRef]

27. da Silva, M.F.; Tort, L.F.; Gomez, M.M.; Assis, R.M.; de Mendonca, M.C.; Volotao Ede, M.; Leite, J.P. Phylogenetic analysis of VP1, VP2, and VP3 gene segments of genotype G5 group A rotavirus strains circulating in Brazil between 1986 and 2005. Virus Res. 2011, 160, 381-388. [CrossRef]

28. Lundgren, O.; Svensson, L. Pathogenesis of rotavirus diarrhea. Microbes Infect. 2001, 3, 1145-1156. [CrossRef]

29. Crawford, S.E.; Ramani, S.; Tate, J.E.; Parashar, U.D.; Svensson, L.; Hagbom, M.; Franco, M.A.; Greenberg, H.B.; O’Ryan, M.; Kang, G.; et al. Rotavirus infection. Nat. Rev. Dis. Primers 2017, 3, 17083. [CrossRef] [PubMed]

30. Hellysaz, A.; Hagbom, M. Understanding the Central Nervous System Symptoms of Rotavirus: A Qualitative Review. Viruses 2021, 13, 658. [CrossRef] [PubMed]

31. Hagbom, M.; Hellysaz, A.; Istrate, C.; Nordgren, J.; Sharma, S.; de-Faria, F.M.; Magnusson, K.E.; Svensson, L. The 5-HT3 Receptor Affects Rotavirus-Induced Motility. J. Virol. 2021, 95, e0075121. [CrossRef] [PubMed] 
32. Istrate, C.; Hagbom, M.; Vikstrom, E.; Magnusson, K.E.; Svensson, L. Rotavirus infection increases intestinal motility but not permeability at the onset of diarrhea. J. Virol. 2014, 88, 3161-3169. [CrossRef] [PubMed]

33. Hemming, M.; Huhti, L.; Rasanen, S.; Salminen, M.; Vesikari, T. Rotavirus antigenemia in children is associated with more severe clinical manifestations of acute gastroenteritis. Pediatr. Infect. Dis. J. 2014, 33, 366-371. [CrossRef] [PubMed]

34. Moon, S.; Wang, Y.; Dennehy, P.; Simonsen, K.A.; Zhang, J.; Jiang, B. Antigenemia, RNAemia, and innate immunity in children with acute rotavirus diarrhea. FEMS Immunol. Med. Microbiol. 2012, 64, 382-391. [CrossRef]

35. Yu, T.H.; Tsai, C.N.; Lai, M.W.; Chen, C.C.; Chao, H.C.; Lin, C.W.; Chiu, C.H.; Chen, S.Y. Antigenemia and cytokine expression in rotavirus gastroenteritis in children. J. Microbiol Immunol. Infect. 2012, 45, 265-270. [CrossRef]

36. Sugata, K.; Taniguchi, K.; Yui, A.; Miyake, F.; Suga, S.; Asano, Y.; Ohashi, M.; Suzuki, K.; Nishimura, N.; Ozaki, T.; et al. Analysis of rotavirus antigenemia and extraintestinal manifestations in children with rotavirus gastroenteritis. Pediatrics 2008, 122, 392-397. [CrossRef]

37. Justino, M.C.A.; Campos, E.A.; Mascarenhas, J.D.P.; Soares, L.S.; Guerra, S.F.S.; Furlaneto, I.P.; Pavao, M.J.C., Jr.; Maciel, T.S.; Farias, F.P.; Bezerra, O.M.; et al. Rotavirus antigenemia as a common event among children hospitalised for severe, acute gastroenteritis in Belem, northern Brazil. BMC Pediatrics 2019, 19, 193. [CrossRef]

38. Ward, R. Mechanisms of protection against rotavirus infection and disease. Pediatr. Infect. Dis. J. 2009, 28, S57-S59. [CrossRef]

39. McNeal, M.M.; Barone, K.S.; Rae, M.N.; Ward, R.L. Effector functions of antibody and CD8+ cells in resolution of rotavirus infection and protection against reinfection in mice. Virology 1995, 214, 387-397. [CrossRef]

40. Jaimes, M.C.; Feng, N.; Greenberg, H.B. Characterization of homologous and heterologous rotavirus-specific T-cell responses in infant and adult mice. J. Virol. 2005, 79, 4568-4579. [CrossRef]

41. Davis, S.K.; Selva, K.J.; Kent, S.J.; Chung, A.W. Serum IgA Fc effector functions in infectious disease and cancer. Immunol. Cell Biol. 2020, 98, 276-286. [CrossRef]

42. Iosef, C.; Chang, K.O.; Azevedo, M.S.; Saif, L.J. Systemic and intestinal antibody responses to NSP4 enterotoxin of Wa human rotavirus in a gnotobiotic pig model of human rotavirus disease. J. Med. Virol. 2002, 68, 119-128. [CrossRef]

43. Yeom, J.S.; Kim, Y.S.; Jun, J.S.; Do, H.J.; Park, J.S.; Seo, J.H.; Park, E.S.; Lim, J.Y.; Woo, H.O.; Park, C.H.; et al. NSP4 antibody levels in rotavirus gastroenteritis patients with seizures. Eur. J. Paediatr. Neurol. EJPN Off. J. Eur. Paediatr. Neurol. Soc. 2017, 21, 367-373. [CrossRef]

44. Vizzi, E.; Calvino, E.; Gonzalez, R.; Perez-Schael, I.; Ciarlet, M.; Kang, G.; Estes, M.K.; Liprandi, F.; Ludert, J.E. Evaluation of serum antibody responses against the rotavirus nonstructural protein NSP4 in children after rhesus rotavirus tetravalent vaccination or natural infection. Clin. Diagn. Lab. Immunol. 2005, 12, 1157-1163. [CrossRef]

45. Caddy, S.L.; Vaysburd, M.; Wing, M.; Foss, S.; Andersen, J.T.; O'Connell, K.; Mayes, K.; Higginson, K.; Iturriza-Gomara, M.; Desselberger, U.; et al. Intracellular neutralisation of rotavirus by VP6-specific IgG. PLoS Pathog. 2020, 16, e1008732. [CrossRef]

46. Lappalainen, S.; Pastor, A.R.; Tamminen, K.; Lopez-Guerrero, V.; Esquivel-Guadarrama, F.; Palomares, L.A.; Vesikari, T.; Blazevic, $\mathrm{V}$. Immune responses elicited against rotavirus middle layer protein VP6 inhibit viral replication in vitro and in vivo. Hum. Vaccines Immunother. 2014, 10, 2039-2047. [CrossRef] [PubMed]

47. Sarkar, R.; Nandi, S.; Lo, M.; Gope, A.; Chawla-Sarkar, M. Viperin, an IFN-Stimulated Protein, Delays Rotavirus Release by Inhibiting Non-Structural Protein 4 (NSP4)-Induced Intrinsic Apoptosis. Viruses 2021, 13, 1324. [CrossRef] [PubMed]

48. Malm, M.; Hyöty, H.; Knip, M.; Vesikari, T.; Blazevic, V. Development of T cell immunity to norovirus and rotavirus in children under five years of age. Sci. Rep. 2019, 9, 3199. [CrossRef] [PubMed]

49. Makela, M.; Marttila, J.; Simell, O.; Ilonen, J. Rotavirus-specific T-cell responses in young prospectively followed-up children. Clin. Exp. Immunol. 2004, 137, 173-178. [CrossRef] [PubMed]

50. Offit, P.A.; Hoffenberg, E.J.; Santos, N.; Gouvea, V. Rotavirus-specific humoral and cellular immune response after primary, symptomatic infection. J. Infect. Dis. 1993, 167, 1436-1440. [CrossRef] [PubMed]

51. Payne, D.C.; Currier, R.L.; Staat, M.A.; Sahni, L.C.; Selvarangan, R.; Halasa, N.B.; Englund, J.A.; Weinberg, G.A.; Boom, J.A.; Szilagyi, P.G.; et al. Epidemiologic Association Between FUT2 Secretor Status and Severe Rotavirus Gastroenteritis in Children in the United States. JAMA Pediatrics 2015, 169, 1040-1045. [CrossRef]

52. Fix, J.; Chandrashekhar, K.; Perez, J.; Bucardo, F.; Hudgens, M.G.; Yuan, L.; Twitchell, E.; Azcarate-Peril, M.A.; Vilchez, S.; Becker-Dreps, S. Association between Gut Microbiome Composition and Rotavirus Vaccine Response among Nicaraguan Infants. Am. J. Trop. Med. Hyg. 2020, 102, 213-219. [CrossRef]

53. Mwila, K.; Chilengi, R.; Simuyandi, M.; Permar, S.R.; Becker-Dreps, S. Contribution of Maternal Immunity to Decreased Rotavirus Vaccine Performance in Low- and Middle-Income Countries. Clin. Vaccine Immunol. CVI 2017, 24, e00405-1. [CrossRef]

54. Monedero, V.; Buesa, J.; Rodriguez-Diaz, J. The Interactions between Host Glycobiology, Bacterial Microbiota, and Viruses in the Gut. Viruses 2018, 10, 96. [CrossRef]

55. Becker-Dreps, S.; Vilchez, S.; Bucardo, F.; Twitchell, E.; Choi, W.S.; Hudgens, M.G.; Perez, J.; Yuan, L. The Association Between Fecal Biomarkers of Environmental Enteropathy and Rotavirus Vaccine Response in Nicaraguan Infants. Pediatr. Infect. Dis. J. 2017, 36, 412-416. [CrossRef]

56. Vlasova, A.N.; Takanashi, S.; Miyazaki, A.; Rajashekara, G.; Saif, L.J. How the gut microbiome regulates host immune responses to viral vaccines. Curr. Opin. Virol. 2019, 37, 16-25. [CrossRef]

57. Desselberger, U. Differences of Rotavirus Vaccine Effectiveness by Country: Likely Causes and Contributing Factors. Pathogens 2017, 6, 65. [CrossRef] [PubMed] 
58. Harris, V.C.; Armah, G.; Fuentes, S.; Korpela, K.E.; Parashar, U.; Victor, J.C.; Tate, J.; de Weerth, C.; Giaquinto, C.; Wiersinga, W.J.; et al. Significant Correlation Between the Infant Gut Microbiome and Rotavirus Vaccine Response in Rural Ghana. J. Infect. Dis. 2017, 215, 34-41. [CrossRef] [PubMed]

59. Harris, V.; Ali, A.; Fuentes, S.; Korpela, K.; Kazi, M.; Tate, J.; Parashar, U.; Wiersinga, W.J.; Giaquinto, C.; de Weerth, C.; et al. Rotavirus vaccine response correlates with the infant gut microbiota composition in Pakistan. Gut Microbes 2018, 9, 93-101. [CrossRef] [PubMed]

60. Nordgren, J.; Svensson, L. Genetic Susceptibility to Human Norovirus Infection: An Update. Viruses 2019, 11, 226. [CrossRef] [PubMed]

61. Lindesmith, L.; Moe, C.; Marionneau, S.; Ruvoen, N.; Jiang, X.; Lindblad, L.; Stewart, P.; LePendu, J.; Baric, R. Human susceptibility and resistance to Norwalk virus infection. Nat. Med. 2003, 9, 548-553. [CrossRef]

62. Frenck, R.; Bernstein, D.I.; Xia, M.; Huang, P.; Zhong, W.; Parker, S.; Dickey, M.; McNeal, M.; Jiang, X. Predicting susceptibility to norovirus GII.4 by use of a challenge model involving humans. J. Infect. Dis. 2012, 206, 1386-1393. [CrossRef]

63. Tan, M.; Jiang, X. Histo-blood group antigens: A common niche for norovirus and rotavirus. Expert Rev. Mol. Med. 2014, 16, e5. [CrossRef]

64. Hu, L.; Crawford, S.E.; Czako, R.; Cortes-Penfield, N.W.; Smith, D.F.; Le Pendu, J.; Estes, M.K.; Prasad, B.V. Cell attachment protein VP8* of a human rotavirus specifically interacts with A-type histo-blood group antigen. Nature 2012, 485, 256-259. [CrossRef]

65. Huang, P.; Xia, M.; Tan, M.; Zhong, W.; Wei, C.; Wang, L.; Morrow, A.; Jiang, X. Spike protein VP8* of human rotavirus recognizes histo-blood group antigens in a type-specific manner. J. Virol. 2012, 86, 4833-4843. [CrossRef]

66. Xu, S.; McGinnis, K.R.; Liu, Y.; Huang, P.; Tan, M.; Stuckert, M.R.; Burnside, R.E.; Jacob, E.G.; Ni, S.; Jiang, X.; et al. Structural basis of $\mathrm{P}[\mathrm{II}]$ rotavirus evolution and host ranges under selection of histo-blood group antigens. Proc. Natl. Acad. Sci. USA 2021, 118. [CrossRef]

67. Sharma, S.; Hagbom, M.; Svensson, L.; Nordgren, J. The Impact of Human Genetic Polymorphisms on Rotavirus Susceptibility, Epidemiology, and Vaccine Take. Viruses 2020, 12, 324. [CrossRef] [PubMed]

68. Farahmand, M.; Jalilvand, S.; Arashkia, A.; Shahmahmoodi, S.; Afchangi, A.; Mollaei-Kandelous, Y.; Shoja, Z. Association between circulating rotavirus genotypes and histo-blood group antigens in the children hospitalized with acute gastroenteritis in Iran. J. Med. Virol. 2021, 93, 4817-4823. [CrossRef] [PubMed]

69. Perez-Ortin, R.; Vila-Vicent, S.; Carmona-Vicente, N.; Santiso-Bellon, C.; Rodriguez-Diaz, J.; Buesa, J. Histo-Blood Group Antigens in Children with Symptomatic Rotavirus Infection. Viruses 2019, 11, 339. [CrossRef] [PubMed]

70. Lee, S.K.; Oh, S.J.; Choi, S.; Choi, S.H.; Shin, S.H.; Lee, E.J.; Cho, E.J.; Hyun, J.; Kim, H.S. Relationship Between Rotavirus P[6] Infection in Korean Neonates and Histo-Blood Group Antigen: A Single-Center Study. Ann. Lab. Med. 2021, 41, 181-189. [CrossRef] [PubMed]

71. MacDonald, J.; Groome, M.J.; Mans, J.; Page, N. Fut2 Secretor Status Influences Susceptibility to Vp4 Strain-Specific Rotavirus Infections in South African Children. Pathogens 2020, 9, 795. [CrossRef]

72. Ouermi, D.; Soubeiga, D.; Nadembega, W.M.C.; Sawadogo, P.M.; Zohoncon, T.M.; Obiri-Yeboah, D.; Djigma, F.W.; Nordgren, J.; Simpore, J. Molecular Epidemiology of Rotavirus in Children under Five in Africa (2006-2016): A Systematic Review. Pak. J. Biol. Sci. 2017, 20, 59-69. [CrossRef]

73. Hu, L.; Sankaran, B.; Laucirica, D.R.; Patil, K.; Salmen, W.; Ferreon, A.C.M.; Tsoi, P.S.; Lasanajak, Y.; Smith, D.F.; Ramani, S.; et al. Glycan recognition in globally dominant human rotaviruses. Nat. Commun. 2018, 9, 2631. [CrossRef]

74. Papp, H.; Borzak, R.; Farkas, S.; Kisfali, P.; Lengyel, G.; Molnar, P.; Melegh, B.; Matthijnssens, J.; Jakab, F.; Martella, V.; et al. Zoonotic transmission of reassortant porcine G4P[6] rotaviruses in Hungarian pediatric patients identified sporadically over a 15 year period. Infect. Genet. Evol. 2013, 19, 71-80. [CrossRef]

75. Zhou, X.; Wang, Y.H.; Ghosh, S.; Tang, W.F.; Pang, B.B.; Liu, M.Q.; Peng, J.S.; Zhou, D.J.; Kobayashi, N. Genomic characterization of G3P[6], G4P[6] and G4P[8] human rotaviruses from Wuhan, China: Evidence for interspecies transmission and reassortment events. Infect. Genet. Evol. 2015, 33, 55-71. [CrossRef]

76. Malasao, R.; Khamrin, P.; Kumthip, K.; Ushijima, H.; Maneekarn, N. Complete genome sequence analysis of rare G4P[6] rotavirus strains from human and pig reveals the evidence for interspecies transmission. Infect. Genet. Evol. 2018, 65, 357-368. [CrossRef]

77. Tacharoenmuang, R.; Guntapong, R.; Upachai, S.; Singchai, P.; Fukuda, S.; Ide, T.; Hatazawa, R.; Sutthiwarakom, K.; Kongjorn, S.; Onvimala, N.; et al. Full genome-based characterization of G4P[6] rotavirus strains from diarrheic patients in Thailand: Evidence for independent porcine-to-human interspecies transmission events. Virus Genes 2021, 57, 338-357. [CrossRef] [PubMed]

78. Mokoena, F.; Esona, M.D.; Seheri, L.M.; Nyaga, M.M.; Magagula, N.B.; Mukaratirwa, A.; Mulindwa, A.; Abebe, A.; Boula, A.; Tsolenyanu, E.; et al. Whole Genome Analysis of African G12P[6] and G12P[8] Rotaviruses Provides Evidence of Porcine-Human Reassortment at NSP2, NSP3, and NSP4. Front. Microbiol. 2020, 11, 604444. [CrossRef] [PubMed]

79. Bucardo, F.; Gonzalez, F.; Reyes, Y.; Blandon, P.; Saif, L.; Nordgren, J. Seroprevalence in Household Raised Pigs Indicate High Exposure to GII Noroviruses in Rural Nicaragua. Zoonoses Public Health 2016, 63, 600-607. [CrossRef]

80. Armah, G.E.; Cortese, M.M.; Dennis, F.E.; Yu, Y.; Morrow, A.L.; McNeal, M.M.; Lewis, K.D.C.; Awuni, D.A.; Armachie, J.; Parashar, U.D. Rotavirus Vaccine Take in Infants Is Associated with Secretor Status. J. Infect. Dis. 2019, 219, 746-749. [CrossRef] [PubMed] 
81. Günaydın, G.; Nordgren, J.; Sharma, S.; Hammarström, L. Association of elevated rotavirus-specific antibody titers with HBGA secretor status in Swedish individuals: The FUT2 gene as a putative susceptibility determinant for infection. Virus Res. 2016, 211, 64-68. [CrossRef]

82. Kazi, A.M.; Cortese, M.M.; Yu, Y.; Lopman, B.; Morrow, A.L.; Fleming, J.A.; McNeal, M.M.; Steele, A.D.; Parashar, U.D.; Zaidi, A.K.M.; et al. Secretor and Salivary ABO Blood Group Antigen Status Predict Rotavirus Vaccine Take in Infants. J. Infect. Dis. 2017, 215, 786-789. [CrossRef]

83. Bennett, A.; Pollock, L.; Jere, K.C.; Pitzer, V.E.; Parashar, U.; Tate, J.E.; Heyderman, R.S.; Mwansambo, C.; French, N.; Nakagomi, O; ; et al. Direct and possible indirect effects of vaccination on rotavirus hospitalisations among children in Malawi four years after programmatic introduction. Vaccine 2018, 36, 7142-7148. [CrossRef] [PubMed]

84. Bucardo, F.; Nordgren, J.; Reyes, Y.; Gonzalez, F.; Sharma, S.; Svensson, L. The Lewis A phenotype is a restriction factor for Rotateq and Rotarix vaccine-take in Nicaraguan children. Sci. Rep. 2018, 9, 1502. [CrossRef] [PubMed]

85. O'Ryan, M.L.; Matson, D.O.; Estes, M.K.; Pickering, L.K. Anti-rotavirus G type-specific and isotype-specific antibodies in children with natural rotavirus infections. J. Infect. Dis. 1994, 169, 504-511. [CrossRef]

86. Velazquez, F.R.; Matson, D.O.; Guerrero, M.L.; Shults, J.; Calva, J.J.; Morrow, A.L.; Glass, R.I.; Pickering, L.K.; Ruiz-Palacios, G.M. Serum antibody as a marker of protection against natural rotavirus infection and disease. J. Infect. Dis. 2000, 182, 1602-1609. [CrossRef]

87. Angel, J.; Steele, A.D.; Franco, M.A. Correlates of protection for rotavirus vaccines: Possible alternative trial endpoints, opportunities, and challenges. Hum. Vaccines Immunother. 2014, 10, 3659-3671. [CrossRef]

88. Patton, J.T. Rotavirus diversity and evolution in the post-vaccine world. Discov. Med. 2012, 13, 85-97. [PubMed]

89. Yuan, L.; Saif, L.J. Induction of mucosal immune responses and protection against enteric viruses: Rotavirus infection of gnotobiotic pigs as a model. Vet. Immunol. Immunopathol. 2002, 87, 147-160. [CrossRef]

90. Lewnard, J.A.; Lopman, B.A.; Parashar, U.D.; Bar-Zeev, N.; Samuel, P.; Guerrero, M.L.; Ruiz-Palacios, G.M.; Kang, G.; Pitzer, V.E. Naturally Acquired Immunity Against Rotavirus Infection and Gastroenteritis in Children: Paired Reanalyses of Birth Cohort Studies. J. Infect. Dis. 2017, 216, 317-326. [CrossRef]

91. Patel, M.; Glass, R.I.; Jiang, B.; Santosham, M.; Lopman, B.; Parashar, U. A systematic review of anti-rotavirus serum IgA antibody titer as a potential correlate of rotavirus vaccine efficacy. J. Infect. Dis. 2013, 208, 284-294. [CrossRef]

92. Hou, Z.; Huang, Y.; Huan, Y.; Pang, W.; Meng, M.; Wang, P.; Yang, M.; Jiang, L.; Cao, X.; Wu, K.K. Anti-Nsp4 Antibody Can Block Rotavirus-Induced Diarrhea in Mice. J. Pediatr. Gastroenterol. Nutr. 2008, 46, 376-385. [CrossRef]

93. Rodríguez-Díaz, J.; Montava, R.; García-Díaz, A.; Buesa, J. Humoral immune response to rotavirus NSP4 enterotoxin in Spanish children. J. Med. Virol. 2005, 77, 317-322. [CrossRef]

94. Johansen, K.; Hinkula, J.; Espinoza, F.; Levi, M.; Zeng, C.; Rudén, U.; Vesikari, T.; Estes, M.; Svensson, L. Humoral and cell-mediated immune responses in humans to the NSP4 enterotoxin of rotavirus. J. Med. Virol. 1999, 59, 369-377. [CrossRef]

95. Ray, P.; Malik, J.; Singh, R.K.; Bhatnagar, S.; Bahl, R.; Kumar, R.; Bhan, M.K. Rotavirus nonstructural protein NSP4 induces heterotypic antibody responses during natural infection in children. J. Infect. Dis. 2003, 187, 1786-1793. [CrossRef] [PubMed]

96. Xu, M.; Fu, Y.; Sun, J.; Zhang, J.; Feng, M.; Cheng, X.; Xu, J. Analysis of rotavirus NSP4 genotypes and age-dependent antibody response against NSP4 in Shanghai, China. Jpn. J. Infect. Dis. 2010, 63, 280-282. [PubMed]

97. Nair, N.; Feng, N.; Blum, L.K.; Sanyal, M.; Ding, S.; Jiang, B.; Sen, A.; Morton, J.M.; He, X.S.; Robinson, W.H.; et al. VP4- and VP7-specific antibodies mediate heterotypic immunity to rotavirus in humans. Sci. Transl Med. 2017, 9, eaam5434. [CrossRef] [PubMed]

98. Parashar, U.D.; Burton, A.; Lanata, C.; Boschi-Pinto, C.; Shibuya, K.; Steele, D.; Birmingham, M.; Glass, R.I. Global mortality associated with rotavirus disease among children in 2004. J. Infect. Dis. 2009, 200 (Suppl. 1), S9-S15. [CrossRef] [PubMed]

99. Troeger, C.; Khalil, I.A.; Rao, P.C.; Cao, S.; Blacker, B.F.; Ahmed, T.; Armah, G.; Bines, J.E.; Brewer, T.G.; Colombara, D.V.; et al. Rotavirus Vaccination and the Global Burden of Rotavirus Diarrhea Among Children Younger Than 5 Years. JAMA Pediatrics 2018, 172, 958-965. [CrossRef] [PubMed]

100. Aliabadi, N.; Antoni, S.; Mwenda, J.M.; Weldegebriel, G.; Biey, J.N.M.; Cheikh, D.; Fahmy, K.; Teleb, N.; Ashmony, H.A.; Ahmed, $\mathrm{H}$; et al. Global impact of rotavirus vaccine introduction on rotavirus hospitalisations among children under 5 years of age, 2008-2016: Findings from the Global Rotavirus Surveillance Network. Lancet Glob. Health 2019, 7, e893-e903. [CrossRef]

101. Soares-Weiser, K.; Bergman, H.; Henschke, N.; Pitan, F.; Cunliffe, N. Vaccines for preventing rotavirus diarrhoea: Vaccines in use. Cochrane Database Syst. Rev. 2019, 3, Cd008521. [CrossRef]

102. Cárcamo-Calvo, R.; Muñoz, C.; Buesa, J.; Rodríguez-Díaz, J.; Gozalbo-Rovira, R. The Rotavirus Vaccine Landscape, an Update. Pathogens 2021, 10, 520. [CrossRef]

103. Patel, M.M.; Hall, A.J.; Vinje, J.; Parashar, U.D. Noroviruses: A comprehensive review. J. Clin. Virol. Off. Publ. Pan. Am. Soc. Clin. Virol. 2009, 44, 1-8. [CrossRef]

104. Blazevic, V.; Malm, M.; Honkanen, H.; Knip, M.; Hyöty, H.; Vesikari, T. Development and maturation of norovirus antibodies in childhood. Microbes Infect. 2016, 18, 263-269. [CrossRef]

105. Bartsch, S.M.; O'Shea, K.J.; Lee, B.Y. The Clinical and Economic Burden of Norovirus Gastroenteritis in the United States. J. Infect. Dis. 2020, 222, 1910-1919. [CrossRef] 
106. Burke, R.M.; Mattison, C.; Marsh, Z.; Shioda, K.; Donald, J.; Salas, S.B.; Naleway, A.L.; Biggs, C.; Schmidt, M.A.; Hall, A.J. Norovirus and Other Viral Causes of Medically Attended Acute Gastroenteritis Across the Age Spectrum: Results from the MAAGE Study in the United States. Clin. Infect. Dis. 2021. [CrossRef]

107. Safadi, M.A.; Riera-Montes, M.; Bravo, L.; Tangsathapornpong, A.; Lagos, R.; Thisyakorn, U.; Linhares, A.C.; Capeding, R.; Prommalikit, O.; Verstraeten, T.; et al. The burden of norovirus disease in children: A multi-country study in Chile, Brazil, Thailand and the Philippines. Int. J. Infect. Dis. IJID Off. Publ. Int. Soc. Infect. Dis. 2021, 109, 77-84. [CrossRef]

108. Tarr, G.A.M.; Pang, X.L.; Zhuo, R.; Lee, B.E.; Chui, L.; Ali, S.; Vanderkooi, O.G.; Michaels-Igbokwe, C.; Tarr, P.I.; MacDonald, S.E.; et al. Attribution of Pediatric Acute Gastroenteritis Episodes and Emergency Department Visits to Norovirus Genogroups I and II. J. Infect. Dis. 2021, 223, 452-461. [CrossRef] [PubMed]

109. Bányai, K.; Estes, M.K.; Martella, V.; Parashar, U.D. Viral gastroenteritis. Lancet 2018, 392, 175-186. [CrossRef]

110. Gurwith, M.; Wenman, W.; Hinde, D.; Feltham, S.; Greenberg, H. A prospective study of rotavirus infection in infants and young children. J. Infect. Dis. 1981, 144, 218-224. [CrossRef] [PubMed]

111. Bhavanam, S.; Freedman, S.B.; Lee, B.E.; Zhuo, R.; Qiu, Y.; Chui, L.; Xie, J.; Ali, S.; Vanderkooi, O.G.; Pang, X.L.; et al. Differences in Illness Severity among Circulating Norovirus Genotypes in a Large Pediatric Cohort with Acute Gastroenteritis. Microorganisms 2020, 8, 1873. [CrossRef] [PubMed]

112. Haddadin, Z.; Batarseh, E.; Hamdan, L.; Stewart, L.S.; Piya, B.; Rahman, H.; Spieker, A.J.; Chappell, J.; Wikswo, M.E.; Dunn, J.R.; et al. Characteristics of GII.4 Norovirus versus other Genotypes in Sporadic Pediatric Infections in Davidson County, Tennessee, USA. Clin. Infect. Dis. 2020, 73, e1525-e1531. [CrossRef] [PubMed]

113. Duan, L.; Yang, X.; Xie, J.; Zhan, W.; Zhang, C.; Liu, H.; Wei, M.; Tang, Y.; Zhao, H.; Luo, M. Prevalence of GII.4 Sydney Norovirus Strains and Associated Factors of Acute Gastroenteritis in Children: 2019/2020 Season in Guangzhou, China. Food Environ. Virol. 2021, 13, 357-367. [CrossRef] [PubMed]

114. Lin, H.Y.; Lai, H.H.; Elaine Chen, Y.F.; Chao, H.C.; Tsai, C.N.; Chang, Y.J.; Chen, S.Y. Clinical significance of the fucosyltransferase 2 (FUT2) secretor status in children hospitalized with acute gastroenteritis in Taiwan. J. Med. Assoc. 2021, 120, 212-216. [CrossRef]

115. Freedman, S.B.; Xie, J.; Lee, B.E.; Ali, S.; Pang, X.L.; Chui, L.; Zhuo, R.; Vanderkooi, O.G.; Tellier, R.; Funk, A.L.; et al. Microbial Etiologies and Clinical Characteristics of Children Seeking Emergency Department Care due to Vomiting in the Absence of Diarrhea. Clin. Infect. Dis. 2021, ciab451. [CrossRef]

116. Prasad, B.V.; Hardy, M.E.; Dokland, T.; Bella, J.; Rossmann, M.G.; Estes, M.K. X-ray crystallographic structure of the Norwalk virus capsid. Science 1999, 286, 287-290. [CrossRef]

117. Cao, S.; Lou, Z.; Tan, M.; Chen, Y.; Liu, Y.; Zhang, Z.; Zhang, X.C.; Jiang, X.; Li, X.; Rao, Z. Structural basis for the recognition of blood group trisaccharides by norovirus. J. Virol. 2007, 81, 5949-5957. [CrossRef] [PubMed]

118. Smith, H.Q.; Smith, T.J. The Dynamic Capsid Structures of the Noroviruses. Viruses 2019, 11, 235. [CrossRef] [PubMed]

119. Mallory, M.L.; Lindesmith, L.C.; Graham, R.L.; Baric, R.S. GII.4 Human Norovirus: Surveying the Antigenic Landscape. Viruses 2019, 11, 177. [CrossRef]

120. Hoa Tran, T.N.; Trainor, E.; Nakagomi, T.; Cunliffe, N.A.; Nakagomi, O. Molecular epidemiology of noroviruses associated with acute sporadic gastroenteritis in children: Global distribution of genogroups, genotypes and GII.4 variants. J. Clin. Virol. Off. Publ. Pan. Am. Soc. Clin. Virol. 2013, 56, 185-193. [CrossRef]

121. Chhabra, P.; de Graaf, M.; Parra, G.I.; Chan, M.C.; Green, K.; Martella, V.; Wang, Q.; White, P.A.; Katayama, K.; Vennema, H.; et al. Updated classification of norovirus genogroups and genotypes. J. Gen. Virol. 2019, 100, 1393-1406. [CrossRef]

122. Farahmand, M.; Moghoofei, M.; Dorost, A.; Shoja, Z.; Ghorbani, S.; Kiani, S.J.; Khales, P.; Esteghamati, A.; Sayyahfar, S.; Jafarzadeh, M.; et al. Global prevalence and genotype distribution of norovirus infection in children with gastroenteritis: A meta-analysis on 6 years of research from 2015 to 2020. Rev. Med. Virol. 2021, e2237. [CrossRef]

123. Cannon, J.L.; Bonifacio, J.; Bucardo, F.; Buesa, J.; Bruggink, L.; Chan, M.C.; Fumian, T.M.; Giri, S.; Gonzalez, M.D.; Hewitt, J.; et al. Global Trends in Norovirus Genotype Distribution among Children with Acute Gastroenteritis. Emerg. Infect. Dis. 2021, 27, 1438-1445. [CrossRef] [PubMed]

124. Teunis, P.F.M.; Moe, C.L.; Liu, P.; Miller, S.E.; Lindesmith, L.; Baric, R.S.; Le Pendu, J.; Calderon, R.L. Norwalk virus: How infectious is it? J. Med. Virol. 2008, 80, 1468-1476. [CrossRef]

125. Ramesh, A.K.; Parreño, V.; Schmidt, P.J.; Lei, S.; Zhong, W.; Jiang, X.; Emelko, M.B.; Yuan, L. Evaluation of the 50\% Infectious Dose of Human Norovirus Cin-2 in Gnotobiotic Pigs: A Comparison of Classical and Contemporary Methods for Endpoint Estimation. Viruses 2020, 12, 955. [CrossRef] [PubMed]

126. Teunis, P.F.M.; Le Guyader, F.S.; Liu, P.; Ollivier, J.; Moe, C.L. Noroviruses are highly infectious but there is strong variation in host susceptibility and virus pathogenicity. Epidemics 2020, 32, 100401. [CrossRef] [PubMed]

127. Guix, S.; Fuentes, C.; Pintó, R.M.; Blanco, A.; Sabrià, A.; Anfruns-Estrada, E.; Garrido, V.R.; Alonso, M.; Bartolomé, R.; Cornejo, T.; et al. Infectivity of Norovirus GI and GII from Bottled Mineral Water during a Waterborne Outbreak, Spain. Emerg. Infect. Dis. 2020, 26, 134-137. [CrossRef] [PubMed]

128. Cheng, H.Y.; Lee, C.C.; Chang, Y.C.; Tsai, C.N.; Chao, H.C.; Tsai, Y.T.; Hsieh, C.H.; Su, S.S.; Chen, S.Y. Viral shedding in gastroenteritis in children caused by variants and novel recombinant norovirus infections. Medicine 2021, 100, e25123. [CrossRef] [PubMed]

129. Patel, M.M.; Widdowson, M.A.; Glass, R.I.; Akazawa, K.; Vinjé, J.; Parashar, U.D. Systematic literature review of role of noroviruses in sporadic gastroenteritis. Emerg. Infect. Dis. 2008, 14, 1224-1231. [CrossRef] 
130. Trivedi, T.K.; Desai, R.; Hall, A.J.; Patel, M.; Parashar, U.D.; Lopman, B.A. Clinical characteristics of norovirus-associated deaths: A systematic literature review. Am. J. Infect. Control. 2013, 41, 654-657. [CrossRef]

131. Hall, A.J.; Lopman, B.A.; Payne, D.C.; Patel, M.M.; Gastañaduy, P.A.; Vinjé, J.; Parashar, U.D. Norovirus disease in the United States. Emerg. Infect. Dis. 2013, 19, 1198-1205. [CrossRef]

132. Tenge, V.R.; Murakami, K.; Salmen, W.; Lin, S.-C.; Crawford, S.E.; Neill, F.H.; Prasad, B.V.V.; Atmar, R.L.; Estes, M.K. Bile Goes Viral. Viruses 2021, 13, 998. [CrossRef]

133. Lindesmith, L.C.; Donaldson, E.F.; Lobue, A.D.; Cannon, J.L.; Zheng, D.P.; Vinje, J.; Baric, R.S. Mechanisms of GII.4 norovirus persistence in human populations. PLoS Med. 2008, 5, e31. [CrossRef]

134. de Rougemont, A.; Ruvoen-Clouet, N.; Simon, B.; Estienney, M.; Elie-Caille, C.; Aho, S.; Pothier, P.; Le Pendu, J.; Boireau, W.; Belliot, G. Qualitative and quantitative analysis of the binding of GII.4 norovirus variants onto human blood group antigens. J. Virol. 2011, 85, 4057-4070. [CrossRef] [PubMed]

135. Anfruns-Estrada, E.; Sabrià, A.; Fuentes, C.; Sabaté, S.; Razquin, E.; Cornejo, T.; Bartolomé, R.; Torner, N.; Izquierdo, C.; Soldevila, N.; et al. Detection of Norovirus in Saliva Samples from Acute Gastroenteritis Cases and Asymptomatic Subjects: Association with Age and Higher Shedding in Stool. Viruses 2020, 12, 1369. [CrossRef]

136. Lindesmith, L.C.; Brewer-Jensen, P.D.; Mallory, M.L.; Jensen, K.; Yount, B.L.; Costantini, V.; Collins, M.H.; Edwards, C.E.; Sheahan, T.P.; Vinjé, J.; et al. Virus-Host Interactions between Nonsecretors and Human Norovirus. Cell. Mol. Gastroenterol. Hepatol. 2020, 10, 245-267. [CrossRef]

137. Cao, R.R.; Ma, X.Z.; Li, W.Y.; Wang, B.N.; Yang, Y.; Wang, H.R.; Kuang, Y.; You, J.Z.; Zhao, Z.Y.; Ren, M.; et al. Epidemiology of norovirus gastroenteritis in hospitalized children under five years old in western China, 2015-2019. J. Microbiol. Immunol. Infect. 2021, S1684. [CrossRef]

138. Manouana, G.P.; Nguema-Moure, P.A.; Mbong Ngwese, M.; Bock, C.; Kremsner, P.G.; Borrmann, S.; Eibach, D.; Mordmüller, B.; Velavan, T.P.; Niendorf, S.; et al. Genetic Diversity of Enteric Viruses in Children under Five Years Old in Gabon. Viruses 2021, 13, 545. [CrossRef]

139. Bucardo, F.; Reyes, Y.; Becker-Dreps, S.; Bowman, N.; Gruber, J.F.; Vinjé, J.; Espinoza, F.; Paniagua, M.; Balmaseda, A.; Svensson, L.; et al. Pediatric norovirus GII.4 infections in Nicaragua, 1999-2015. Infect. Genet. Evol. 2017, 55, 305-312. [CrossRef] [PubMed]

140. Utsumi, T.; Lusida, M.I.; Dinana, Z.; Wahyuni, R.M.; Soegijanto, S.; Athiyyah, A.F.; Sudarmo, S.M.; Ranuh, R.G.; Darma, A.; Yamani, L.N.; et al. Molecular epidemiology and genetic diversity of norovirus infection in children hospitalized with acute gastroenteritis in East Java, Indonesia in 2015-2019. Infect. Genet. Evol. 2021, 88, 104703. [CrossRef] [PubMed]

141. Fang, Y.; Dong, Z.; Liu, Y.; Wang, W.; Hou, M.; Wu, J.; Wang, L.; Zhao, Y. Molecular epidemiology and genetic diversity of norovirus among hospitalized children with acute gastroenteritis in Tianjin, China, 2018-2020. BMC Infect. Dis. 2021, 21, 682. [CrossRef]

142. Rossouw, E.; Brauer, M.; Meyer, P.; du Plessis, N.M.; Avenant, T.; Mans, J. Virus Etiology, Diversity and Clinical Characteristics in South African Children Hospitalised with Gastroenteritis. Viruses 2021, 13, 215. [CrossRef]

143. Saito, M.; Tsukagoshi, H.; Ishigaki, H.; Aso, J.; Ishii, H.; Okayama, K.; Ryo, A.; Ishioka, T.; Kuroda, M.; Saruki, N.; et al. Molecular evolution of the capsid (VP1) region in human norovirus genogroup II genotype 3. Heliyon 2020, 6, e03835. [CrossRef]

144. Ludwig-Begall, L.F.; Mauroy, A.; Thiry, E. Norovirus recombinants: Recurrent in the field, recalcitrant in the lab-A scoping review of recombination and recombinant types of noroviruses. J. Gen. Virol. 2018, 99, 970-988. [CrossRef]

145. Ruis, C.; Roy, S.; Brown, J.R.; Allen, D.J.; Goldstein, R.A.; Breuer, J. The emerging GII.P16-GII.4 Sydney 2012 norovirus lineage is circulating worldwide, arose by late-2014 and contains polymerase changes that may increase virus transmission. PLoS ONE 2017, 12, e0179572. [CrossRef]

146. Lindesmith, L.C.; Brewer-Jensen, P.D.; Mallory, M.L.; Debbink, K.; Swann, E.W.; Vinje, J.; Baric, R.S. Antigenic Characterization of a Novel Recombinant GII.P16-GII.4 Sydney Norovirus Strain with Minor Sequence Variation Leading to Antibody Escape. J. Infect. Dis. 2018, 217, 1145-1152. [CrossRef]

147. Barclay, L.; Cannon, J.L.; Wikswo, M.E.; Phillips, A.R.; Browne, H.; Montmayeur, A.M.; Tatusov, R.L.; Burke, R.M.; Hall, A.J.; Vinje, J. Emerging Novel GII.P16 Noroviruses Associated with Multiple Capsid Genotypes. Viruses 2019, 11, 535. [CrossRef] [PubMed]

148. Tohma, K.; Lepore, C.J.; Martinez, M.; Degiuseppe, J.I.; Khamrin, P.; Saito, M.; Mayta, H.; Nwaba, A.U.A.; Ford-Siltz, L.A.; Green, K.Y.; et al. Genome-wide analyses of human noroviruses provide insights on evolutionary dynamics and evidence of coexisting viral populations evolving under recombination constraints. PLoS Pathog. 2021, 17, e1009744. [CrossRef] [PubMed]

149. Alsuwaidi, A.R.; Al Dhaheri, K.; Al Hamad, S.; George, J.; Ibrahim, J.; Ghatasheh, G.; Issa, M.; Al-Hammadi, S.; Narchi, H. Etiology of diarrhea by multiplex polymerase chain reaction among young children in the United Arab Emirates: A case-control study. BMC Infect. Dis. 2021, 21, 7. [CrossRef] [PubMed]

150. Dey, S.K.; Sharif, N.; Billah, B.; Siddique, T.T.; Islam, T.; Parvez, A.K.; Talukder, A.A.; Phan, T.; Ushijima, H. Molecular epidemiology and genetic diversity of norovirus infection in children with acute gastroenteritis in Bangladesh, 2014-2019. J. Med. Virol. 2021, 93, 3564-3571. [CrossRef] [PubMed]

151. Vilchez, S.; Reyes, D.; Paniagua, M.; Bucardo, F.; Möllby, R.; Weintraub, A. Prevalence of diarrhoeagenic Escherichia coli in children from León, Nicaragua. J. Med. Microbiol. 2009, 58, 630-637. [CrossRef]

152. Hesse, S.; Neill, F.H.; Estes, M.K.; Shanker, S.; Prasad, B.V.; Ferreira, J.; Atmar, R.L. Serological Responses to a Norovirus Nonstructural Fusion Protein after Vaccination and Infection. Clin. Vaccine Immunol. CVI 2016, 23, 181-183. [CrossRef] [PubMed] 
153. Kulkarni, R.; Lole, K.; Chitambar, S.D. Seroprevalence of antibodies against GII.4 norovirus among children in Pune, India. J. Med. Virol. 2016, 88, 1636-1640. [CrossRef]

154. Parker, S.P.; Cubitt, W.D.; Jiang, X. Enzyme immunoassay using baculovirus-expressed human calicivirus (Mexico) for the measurement of IgG responses and determining its seroprevalence in London, UK. J. Med. Virol. 1995, 46, 194-200. [CrossRef]

155. Taylor, M.B.; Parker, S.; Grabow, W.O.; Cubitt, W.D. An epidemiological investigation of Norwalk virus infection in South Africa. Epidemiol. Infect. 1996, 116, 203-206. [CrossRef] [PubMed]

156. Parker, S.P.; Cubitt, W.D.; Jiang, X.J.; Estes, M.K. Seroprevalence studies using a recombinant Norwalk virus protein enzyme immunoassay. J. Med. Virol. 1994, 42, 146-150. [CrossRef] [PubMed]

157. Arnold, B.F.; Martin, D.L.; Juma, J.; Mkocha, H.; Ochieng, J.B.; Cooley, G.M.; Omore, R.; Goodhew, E.B.; Morris, J.F.; Costantini, V.; et al. Enteropathogen antibody dynamics and force of infection among children in low-resource settings. eLife 2019, 8, e45594. [CrossRef] [PubMed]

158. Thorne, L.; Nalwoga, A.; Mentzer, A.J.; de Rougemont, A.; Hosmillo, M.; Webb, E.; Nampiija, M.; Muhwezi, A.; Carstensen, T.; Gurdasani, D.; et al. The First Norovirus Longitudinal Seroepidemiological Study from Sub-Saharan Africa Reveals High Seroprevalence of Diverse Genotypes Associated with Host Susceptibility Factors. J. Infect. Dis. 2018, 218, 716-725. [CrossRef]

159. Menon, V.K.; George, S.; Shanti, A.A.; Saravanabavan, A.; Samuel, P.; Ramani, S.; Estes, M.K.; Kang, G. Exposure to human and bovine noroviruses in a birth cohort in southern India from 2002 to 2006. J. Clin. Microbiol. 2013, 51, 2391-2395. [CrossRef]

160. van Beek, J.; de Graaf, M.; Xia, M.; Jiang, X.; Vinje, J.; Beersma, M.; de Bruin, E.; van de Vijver, D.; Holwerda, M.; van Houten, M.; et al. Comparison of norovirus genogroup I, II and IV seroprevalence among children in the Netherlands, 1963, 1983 and 2006. J. Gen. Virol. 2016, 97, 2255-2264. [CrossRef]

161. Grytdal, S.P.; DeBess, E.; Lee, L.E.; Blythe, D.; Ryan, P.; Biggs, C.; Cameron, M.; Schmidt, M.; Parashar, U.D.; Hall, A.J. Incidence of Norovirus and Other Viral Pathogens That Cause Acute Gastroenteritis (AGE) among Kaiser Permanente Member Populations in the United States, 2012-2013. PLoS ONE 2016, 11, e0148395. [CrossRef]

162. Poulain, C.; Galeno, H.; Loayza, S.; Vergara, N.; Valdivieso, F.; Coria, P.; Sotomayor, V.; Simian, M.E.; Acevedo, J.; Farfán, M.J. Molecular detection of gastrointestinal pathogens among children under 5 years old with diarrhea in a hospital center for rotavirus sentinel surveillance in Chile. Rev. Chil. Infectol. 2021, 38, 54-60. [CrossRef] [PubMed]

163. Lindesmith, L.; Moe, C.; Lependu, J.; Frelinger, J.A.; Treanor, J.; Baric, R.S. Cellular and humoral immunity following Snow Mountain virus challenge. J. Virol. 2005, 79, 2900-2909. [CrossRef] [PubMed]

164. Lindesmith, L.C.; Beltramello, M.; Donaldson, E.F.; Corti, D.; Swanstrom, J.; Debbink, K.; Lanzavecchia, A.; Baric, R.S. Immunogenetic mechanisms driving norovirus GII.4 antigenic variation. PLoS Pathog. 2012, 8, e1002705. [CrossRef] [PubMed]

165. Saito, M.; Goel-Apaza, S.; Espetia, S.; Velasquez, D.; Cabrera, L.; Loli, S.; Crabtree, J.E.; Black, R.E.; Kosek, M.; Checkley, W.; et al. Multiple norovirus infections in a birth cohort in a Peruvian Periurban community. Clin. Infect. Dis. 2014, 58, 483-491. [CrossRef] [PubMed]

166. Cannon, J.L.; Lopman, B.A.; Payne, D.C.; Vinjé, J. Birth Cohort Studies Assessing Norovirus Infection and Immunity in Young Children: A Review. Clin. Infect. Dis. 2019, 69, 357-365. [CrossRef]

167. Parra, G.I.; Green, K.Y. Sequential gastroenteritis episodes caused by 2 norovirus genotypes. Emerg. Infect. Dis. 2014, 20, 1016-1018. [CrossRef] [PubMed]

168. Chhabra, P.; Rouhani, S.; Browne, H.; Peñataro Yori, P.; Siguas Salas, M.; Paredes Olortegui, M.; Moulton, L.H.; Kosek, M.N.; Vinjé, J. Homotypic and Heterotypic Protection and Risk of Reinfection Following Natural Norovirus Infection in a Highly Endemic Setting. Clin. Infect. Dis. 2021, 72, 222-229. [CrossRef]

169. Blazevic, V.; Malm, M.; Salminen, M.; Oikarinen, S.; Hyöty, H.; Veijola, R.; Vesikari, T. Multiple consecutive norovirus infections in the first 2 years of life. Eur. J. Pediatr. 2015, 174, 1679-1683. [CrossRef]

170. Mateo, R.; Lindesmith, L.C.; Garg, S.J.; Gottlieb, K.; Lin, K.; Said, S.; Leon, J.S.; Sims, A.C.; Weber, D.J.; Baric, R.S.; et al. Production and Clinical Evaluation of Norwalk GI.1 Virus Lot 001-09NV in Norovirus Vaccine Development. J. Infect. Dis. 2020, 221, 919-926. [CrossRef]

171. Lindesmith, L.C.; McDaniel, J.R.; Changela, A.; Verardi, R.; Kerr, S.A.; Costantini, V.; Brewer-Jensen, P.D.; Mallory, M.L.; Voss, W.N.; Boutz, D.R.; et al. Sera Antibody Repertoire Analyses Reveal Mechanisms of Broad and Pandemic Strain Neutralizing Responses after Human Norovirus Vaccination. Immunity 2019, 50, 1530-1541.e1538. [CrossRef]

172. Alvarado, G.; Salmen, W.; Ettayebi, K.; Hu, L.; Sankaran, B.; Estes, M.K.; Venkataram Prasad, B.V.; Crowe, J.E., Jr. Broadly cross-reactive human antibodies that inhibit genogroup I and II noroviruses. Nat. Commun. 2021, 12, 4320. [CrossRef]

173. Malm, M.; Uusi-Kerttula, H.; Vesikari, T.; Blazevic, V. High serum levels of norovirus genotype-specific blocking antibodies correlate with protection from infection in children. J. Infect. Dis. 2014, 210, 1755-1762. [CrossRef]

174. Alexander, E.; Hommeida, S.; Stephens, M.C.; Manini, M.L.; Absah, I. The Role of Oral Administration of Immunoglobulin in Managing Diarrheal Illness in Immunocompromised Children. Paediatr. Drugs 2020, 22, 331-334. [CrossRef]

175. Nussbaum, E.Z.; Azar, M.M.; Cohen, E.; McManus, D.; Topal, J.E.; Malinis, M. Orally Administered Human Immunoglobulin Therapy for Norovirus Enteritis in Solid Organ Transplant Recipients: A Case Series at a Single Academic Transplant Center. Clin. Infect. Dis. 2020, 71, e206-e209. [CrossRef] [PubMed]

176. Shillitoe, B.M.J.; Ponsford, M.; Slatter, M.A.; Evans, J.; Struik, S.; Cosgrove, M.; Doull, I.; Jolles, S.; Gennery, A.R. Haematopoietic Stem Cell Transplant for Norovirus-Induced Intestinal Failure in X-linked Agammaglobulinemia. J. Clin. Immunol. 2021, 41, 1574-1581. [CrossRef] 
177. Jain, P.; Mishra, A.; Gupta, D.; Kulkarni, S. Chronic enteropathy-related malabsorption syndrome in an adult with common variable immunodeficiency and symptomatic norovirus infection of the gut. BMJ Case Rep. 2021, 14, e241752. [CrossRef] [PubMed]

178. Lindesmith, L.C.; Brewer-Jensen, P.D.; Mallory, M.L.; Yount, B.; Collins, M.H.; Debbink, K.; Graham, R.L.; Baric, R.S. Human Norovirus Epitope D Plasticity Allows Escape from Antibody Immunity without Loss of Capacity for Binding Cellular Ligands. J. Virol. 2019, 93, e01813-18. [CrossRef] [PubMed]

179. Atmar, R.L.; Bernstein, D.I.; Lyon, G.M.; Treanor, J.J.; Al-Ibrahim, M.S.; Graham, D.Y.; Vinje, J.; Jiang, X.; Gregoricus, N.; Frenck, R.W.; et al. Serological Correlates of Protection against a GII.4 Norovirus. Clin. Vaccine Immunol. CVI 2015, 22, 923-929. [CrossRef] [PubMed]

180. Ramani, S.; Neill, F.H.; Opekun, A.R.; Gilger, M.A.; Graham, D.Y.; Estes, M.K.; Atmar, R.L. Mucosal and Cellular Immune Responses to Norwalk Virus. J. Infect. Dis. 2015, 212, 397-405. [CrossRef]

181. Lindesmith, L.C.; Ferris, M.T.; Mullan, C.W.; Ferreira, J.; Debbink, K.; Swanstrom, J.; Richardson, C.; Goodwin, R.R.; Baehner, F.; Mendelman, P.M.; et al. Broad blockade antibody responses in human volunteers after immunization with a multivalent norovirus VLP candidate vaccine: Immunological analyses from a phase I clinical trial. PLoS Med. 2015, 12, e1001807. [CrossRef] [PubMed]

182. Reeck, A.; Kavanagh, O.; Estes, M.K.; Opekun, A.R.; Gilger, M.A.; Graham, D.Y.; Atmar, R.L. Serological correlate of protection against norovirus-induced gastroenteritis. J. Infect. Dis. 2010, 202, 1212-1218. [CrossRef]

183. Kim, L.; Liebowitz, D.; Lin, K.; Kasparek, K.; Pasetti, M.F.; Garg, S.J.; Gottlieb, K.; Trager, G.; Tucker, S.N. Safety and immunogenicity of an oral tablet norovirus vaccine, a phase I randomized, placebo-controlled trial. JCI Insight 2018, 3, e121077. [CrossRef]

184. Treanor, J.; Dolin, R.; Madore, H.P. Production of a monoclonal antibody against the Snow Mountain agent of gastroenteritis by in vitro immunization of murine spleen cells. Proc. Natl. Acad. Sci. USA 1988, 85, 3613-3617. [CrossRef] [PubMed]

185. Harrington, P.R.; Lindesmith, L.; Yount, B.; Moe, C.L.; Baric, R.S. Binding of Norwalk virus-like particles to ABH histo-blood group antigens is blocked by antisera from infected human volunteers or experimentally vaccinated mice. J. Virol. 2002, 76, 12335-12343. [CrossRef]

186. Atmar, R.L.; Ettayebi, K.; Ayyar, B.V.; Neill, F.H.; Braun, R.P.; Ramani, S.; Estes, M.K. Comparison of Microneutralization and Histo-Blood Group Antigen-Blocking Assays for Functional Norovirus Antibody Detection. J. Infect. Dis. 2020, 221, 739-743. [CrossRef]

187. Alvarado, G.; Ettayebi, K.; Atmar, R.L.; Bombardi, R.G.; Kose, N.; Estes, M.K.; Crowe, J.E., Jr. Human Monoclonal Antibodies That Neutralize Pandemic GII.4 Noroviruses. Gastroenterology 2018, 155, 1898-1907. [CrossRef] [PubMed]

188. Tohma, K.; Lepore, C.J.; Gao, Y.; Ford-Siltz, L.A.; Parra, G.I. Population Genomics of GII.4 Noroviruses Reveal Complex Diversification and New Antigenic Sites Involved in the Emergence of Pandemic Strains. mBio 2019, 10, e02202-19. [CrossRef]

189. Kendra, J.A.; Tohma, K.; Ford-Siltz, L.A.; Lepore, C.J.; Parra, G.I. Antigenic cartography reveals complexities of genetic determinants that lead to antigenic differences among pandemic GII.4 noroviruses. Proc. Natl. Acad. Sci. USA 2021, 118 , e2015874118. [CrossRef]

190. Atmar, R.L.; Bernstein, D.I.; Harro, C.D.; Al-Ibrahim, M.S.; Chen, W.H.; Ferreira, J.; Estes, M.K.; Graham, D.Y.; Opekun, A.R.; Richardson, C.; et al. Norovirus vaccine against experimental human Norwalk Virus illness. N. Engl. J. Med. 2011, 365, $2178-2187$. [CrossRef]

191. Bernstein, D.I.; Atmar, R.L.; Lyon, G.M.; Treanor, J.J.; Chen, W.H.; Jiang, X.; Vinjé, J.; Gregoricus, N.; Frenck, R.W., Jr.; Moe, C.L.; et al. Norovirus vaccine against experimental human GII.4 virus illness: A challenge study in healthy adults. J. Infect. Dis. 2015, 211, 870-878. [CrossRef] [PubMed]

192. Knoll, B.M.; Lindesmith, L.C.; Yount, B.L.; Baric, R.S.; Marty, F.M. Resolution of diarrhea in an immunocompromised patient with chronic norovirus gastroenteritis correlates with constitution of specific antibody blockade titer. Infection 2016, 44, 551-554. [CrossRef] [PubMed]

193. Lindesmith, L.C.; Beltramello, M.; Swanstrom, J.; Jones, T.A.; Corti, D.; Lanzavecchia, A.; Baric, R.S. Serum Immunoglobulin a Cross-Strain Blockade of Human Noroviruses. Open Forum Infect. Dis. 2015, 2, ofv084. [CrossRef] [PubMed]

194. Sapparapu, G.; Czakó, R.; Alvarado, G.; Shanker, S.; Prasad, B.V.; Atmar, R.L.; Estes, M.K.; Crowe, J.E., Jr. Frequent Use of the IgA Isotype in Human B Cells Encoding Potent Norovirus-Specific Monoclonal Antibodies That Block HBGA Binding. PLoS Pathog. 2016, 12, e1005719. [CrossRef]

195. Tamminen, K.; Malm, M.; Vesikari, T.; Blazevic, V. Norovirus-specific mucosal antibodies correlate to systemic antibodies and block norovirus virus-like particles binding to histo-blood group antigens. Clin. Immunol. 2018, 197, 110-117. [CrossRef]

196. Costantini, V.P.; Cooper, E.M.; Hardaker, H.L.; Lee, L.E.; DeBess, E.E.; Cieslak, P.R.; Hall, A.J.; Vinjé, J. Humoral and Mucosal Immune Responses to Human Norovirus in the Elderly. J. Infect. Dis. 2020, 221, 1864-1874. [CrossRef]

197. Blazevic, V.; Malm, M.; Vesikari, T. Induction of homologous and cross-reactive GII.4-specific blocking antibodies in children after GII.4 New Orleans norovirus infection. J. Med. Virol. 2015, 87, 1656-1661. [CrossRef]

198. Debbink, K.; Lindesmith, L.C.; Donaldson, E.F.; Costantini, V.; Beltramello, M.; Corti, D.; Swanstrom, J.; Lanzavecchia, A.; Vinje, J.; Baric, R.S. Emergence of new pandemic GII.4 Sydney norovirus strain correlates with escape from herd immunity. J. Infect. Dis. 2013, 208, 1877-1887. [CrossRef] 
199. Lindesmith, L.C.; Costantini, V.; Swanstrom, J.; Debbink, K.; Donaldson, E.F.; Vinje, J.; Baric, R.S. Emergence of a Norovirus GII.4 Strain Correlates with Changes in Evolving Blockade Epitopes. J. Virol. 2013, 87, 2803-2813. [CrossRef]

200. Lindesmith, L.C.; Donaldson, E.; Leon, J.; Moe, C.L.; Frelinger, J.A.; Johnston, R.E.; Weber, D.J.; Baric, R.S. Heterotypic humoral and cellular immune responses following Norwalk virus infection. J. Virol. 2010, 84, 1800-1815. [CrossRef]

201. Sherwood, J.; Mendelman, P.M.; Lloyd, E.; Liu, M.; Boslego, J.; Borkowski, A.; Jackson, A.; Faix, D. Efficacy of an intramuscular bivalent norovirus GI.1/GII.4 virus-like particle vaccine candidate in healthy US adults. Vaccine 2020, 38, 6442-6449. [CrossRef] [PubMed]

202. Atmar, R.L.; Baehner, F.; Cramer, J.P.; Song, E.; Borkowski, A.; Mendelman, P.M. Rapid Responses to 2 Virus-Like Particle Norovirus Vaccine Candidate Formulations in Healthy Adults: A Randomized Controlled Trial. J. Infect. Dis. 2016, 214, 845-853. [CrossRef]

203. Atmar, R.L.; Baehner, F.; Cramer, J.P.; Lloyd, E.; Sherwood, J.; Borkowski, A.; Mendelman, P.M. Persistence of Antibodies to 2 Virus-Like Particle Norovirus Vaccine Candidate Formulations in Healthy Adults: 1-Year Follow-up with Memory Probe Vaccination. J. Infect. Dis. 2019, 220, 603-614. [CrossRef] [PubMed]

204. Ford-Siltz, L.A.; Wales, S.; Tohma, K.; Gao, Y.; Parra, G.I. Genotype-Specific Neutralization of Norovirus is Mediated by Antibodies Against the Protruding Domain of the Major Capsid Protein. J. Infect. Dis. 2020, jiaa116. [CrossRef] [PubMed]

205. Debbink, K.; Lindesmith, L.C.; Baric, R.S. The state of norovirus vaccines. Clin. Infect. Dis. 2014, 58, 1746-1752. [CrossRef] [PubMed]

206. LoBue, A.D.; Lindesmith, L.; Yount, B.; Harrington, P.R.; Thompson, J.M.; Johnston, R.E.; Moe, C.L.; Baric, R.S. Multivalent norovirus vaccines induce strong mucosal and systemic blocking antibodies against multiple strains. Vaccine 2006, 24, 5220-5234. [CrossRef]

207. Lindesmith, L.C.; Mallory, M.L.; Jones, T.A.; Richardson, C.; Goodwin, R.R.; Baehner, F.; Mendelman, P.M.; Bargatze, R.F.; Baric, R.S. Impact of Pre-exposure History and Host Genetics on Antibody Avidity Following Norovirus Vaccination. J. Infect. Dis. 2017, 215, 984-991. [CrossRef]

208. Ramani, S.; Neill, F.H.; Ferreira, J.; Treanor, J.J.; Frey, S.E.; Topham, D.J.; Goodwin, R.R.; Borkowski, A.; Baehner, F.; Mendelman, P.M.; et al. B-Cell Responses to Intramuscular Administration of a Bivalent Virus-Like Particle Human Norovirus Vaccine. Clin. Vaccine Immunol. CVI 2017, 24, e00571-16. [CrossRef]

209. Bartsch, S.M.; O'Shea, K.J.; Wedlock, P.T.; Ferguson, M.C.; Siegmund, S.S.; Lee, B.Y. Potential Clinical and Economic Value of Norovirus Vaccination in the Community Setting. Am. J. Prev. Med. 2021, 60, 360-368. [CrossRef]

210. Vielot, N.A.; González, F.; Reyes, Y.; Zepeda, O.; Blette, B.; Paniagua, M.; Toval-Ruíz, C.; Diez-Valcarce, M.; Hudgens, M.G.; Gutiérrez, L.; et al. Risk Factors and Clinical Profile of Sapovirus-associated Acute Gastroenteritis in Early Childhood: A Nicaraguan Birth Cohort Study. J. Pediatr. Infect. Dis. 2021, 40, 220-226. [CrossRef]

211. Farkas, T.; Deng, X.; Ruiz-Palacios, G.; Morrow, A.; Jiang, X. Development of an enzyme immunoassay for detection of sapovirusspecific antibodies and its application in a study of seroprevalence in children. J. Clin. Microbiol. 2006, 44, 3674-3679. [CrossRef] [PubMed]

212. Donowitz, J.R.; Drew, J.; Taniuchi, M.; Platts-Mills, J.A.; Alam, M.; Ferdous, T.; Shama, T.; Islam, M.O.; Kabir, M.; Nayak, U.; et al. Diarrheal Pathogens Associated with Growth and Neurodevelopment. Clin. Infect. Dis. 2021, 73, e683-e691. [CrossRef] [PubMed]

213. Halasa, N.; Piya, B.; Stewart, L.S.; Rahman, H.; Payne, D.C.; Woron, A.; Thomas, L.; Constantine-Renna, L.; Garman, K.; McHenry, R.; et al. The Changing Landscape of Pediatric Viral Enteropathogens in the Post-Rotavirus Vaccine Era. Clin. Infect. Dis. 2021, 72, 576-585. [CrossRef] [PubMed]

214. Inns, T.; Wilson, D.; Manley, P.; Harris, J.P.; O’Brien, S.J.; Vivancos, R. What proportion of care home outbreaks are caused by norovirus? An analysis of viral causes of gastroenteritis outbreaks in care homes, North East England, 2016-2018. BMC Infect. Dis. 2019, 20, 2. [CrossRef]

215. Daniel-Wayman, S.; Fahle, G.; Palmore, T.; Green, K.Y.; Prevots, D.R. Norovirus, astrovirus, and sapovirus among immunocompromised patients at a tertiary care research hospital. Diagn. Microbiol. Infect. Dis. 2018, 92, 143-146. [CrossRef]

216. Pietsch, C.; Liebert, U.G. Intrahost viral evolution during chronic sapovirus infections. J. Clin. Virol. Off. Publ. Pan. Am. Soc. Clin. Virol. 2019, 113, 1-7. [CrossRef]

217. Diez Valcarce, M.; Kambhampati, A.K.; Calderwood, L.E.; Hall, A.J.; Mirza, S.A.; Vinjé, J. Global distribution of sporadic sapovirus infections: A systematic review and meta-analysis. PLoS ONE 2021, 16, e0255436. [CrossRef]

218. Chang, K.O.; Sosnovtsev, S.V.; Belliot, G.; Wang, Q.; Saif, L.J.; Green, K.Y. Reverse genetics system for porcine enteric calicivirus, a prototype sapovirus in the Caliciviridae. J. Virol. 2005, 79, 1409-1416. [CrossRef]

219. Human Calicivirus Typing Tool. Available online: https:/ / norovirus.ng.philab.cdc.gov/ (accessed on 14 June 2021).

220. Becker-Dreps, S.; González, F.; Bucardo, F. Sapovirus: An emerging cause of childhood diarrhea. Curr. Opin. Infect. Dis. 2020, 33, 388-397. [CrossRef]

221. Bucardo, F.; Carlsson, B.; Nordgren, J.; Larson, G.; Blandon, P.; Vilchez, S.; Svensson, L. Susceptibility of children to sapovirus infections, Nicaragua, 2005-2006. Emerg. Infect. Dis. 2012, 18, 1875-1878. [CrossRef]

222. Takagi, H.; Oka, T.; Shimoike, T.; Saito, H.; Kobayashi, T.; Takahashi, T.; Tatsumi, C.; Kataoka, M.; Wang, Q.; Saif, L.J.; et al. Human sapovirus propagation in human cell lines supplemented with bile acids. Proc. Natl. Acad. Sci. USA 2020, 117, 32078-32085. [CrossRef] 
223. Iritani, N.; Yamamoto, S.P.; Abe, N.; Kubo, H.; Oka, T.; Kaida, A. Epidemics of GI.2 sapovirus in gastroenteritis outbreaks during 2012-2013 in Osaka City, Japan. J. Med. Virol. 2016, 88, 1187-1193. [CrossRef] [PubMed]

224. Lyman, W.H.; Walsh, J.F.; Kotch, J.B.; Weber, D.J.; Gunn, E.; Vinjé, J. Prospective study of etiologic agents of acute gastroenteritis outbreaks in child care centers. J. Pediatr. 2009, 154, 253-257. [CrossRef] [PubMed]

225. Hassan-Ríos, E.; Torres, P.; Muñoz, E.; Matos, C.; Hall, A.; Gregoricus, N.; Vinjé, J. Sapovirus Gastroenteritis in Preschool Center, Puerto Rico, 2011. Emerg. Infect. Dis. 2013, 19, 174. [CrossRef]

226. Wang, J.; Li, Y.; Kong, X.; Li, H.; Zhang, Q.; Jin, M.; Wang, Y.; Duan, Z.-J. Two gastroenteritis outbreaks caused by sapovirus in Shenzhen, China. J. Med. Virol. 2018, 90, 1695-1702. [CrossRef] [PubMed]

227. Johansson, P.J.; Bergentoft, K.; Larsson, P.A.; Magnusson, G.; Widell, A.; Thorhagen, M.; Hedlund, K.O. A nosocomial sapovirusassociated outbreak of gastroenteritis in adults. Scand. J. Infect. Dis. 2005, 37, 200-204. [CrossRef] [PubMed]

228. Pang, X.L.; Lee, B.E.; Tyrrell, G.J.; Preiksaitis, J.K. Epidemiology and genotype analysis of sapovirus associated with gastroenteritis outbreaks in Alberta, Canada: 2004-2007. J. Infect. Dis. 2009, 199, 547-551. [CrossRef]

229. Lee, L.E.; Cebelinski, E.A.; Fuller, C.; Keene, W.E.; Smith, K.; Vinjé, J.; Besser, J.M. Sapovirus outbreaks in long-term care facilities, Oregon and Minnesota, USA, 2002-2009. Emerg. Infect. Dis. 2012, 18, 873-876. [CrossRef]

230. Nidaira, M.; Taira, K.; Kato, T.; Arakaki, E.; Kyan, H.; Takara, T.; Okano, S.; Kuba, Y.; Kudaka, J.; Noda, M. Phylogenetic Analysis of Sapovirus Detected from an Outbreak of Acute Gastroenteritis on Ishigaki Island (Okinawa Prefecture, Japan) in 2012. Jpn. J. Infect. Dis. 2014, 67, 141-143. [CrossRef]

231. Rogawski McQuade, E.T.; Liu, J.; Kang, G.; Kosek, M.N.; Lima, A.A.M.; Bessong, P.O.; Samie, A.; Haque, R.; Mduma, E.R.; Shrestha, S.; et al. Protection from Natural Immunity Against Enteric Infections and Etiology-Specific Diarrhea in a Longitudinal Birth Cohort. J. Infect. Dis. 2020, 222, 1858-1868. [CrossRef]

232. Chiba, S.; Sakuma, Y.; Kogasaka, R.; Akihara, M.; Horino, K.; Nakao, T.; Fukui, S. An outbreak of gastroenteritis associated with calicivirus in an infant home. J. Med. Virol. 1979, 4, 249-254. [CrossRef] [PubMed]

233. Cubitt, W.D.; McSwiggan, D.A. Seroepidemiological survey of the prevalence of antibodies to a strain of human calicivirus. J. Med. Virol. 1987, 21, 361-368. [CrossRef] [PubMed]

234. Nakata, S.; Chiba, S.; Terashima, H.; Yokoyama, T.; Nakao, T. Humoral immunity in infants with gastroenteritis caused by human calicivirus. J. Infect. Dis. 1985, 152, 274-279. [CrossRef] [PubMed]

235. Peñaflor-Téllez, Y.; Trujillo-Uscanga, A.; Escobar-Almazán, J.A.; Gutiérrez-Escolano, A.L. Immune Response Modulation by Caliciviruses. Front. Immunol. 2019, 10, 2334. [CrossRef]

236. Roos-Weil, D.; Ambert-Balay, K.; Lanternier, F.; Mamzer-Bruneel, M.F.; Nochy, D.; Pothier, P.; Avettand-Fenoel, V.; Anglicheau, D.; Snanoudj, R.; Bererhi, L.; et al. Impact of norovirus/sapovirus-related diarrhea in renal transplant recipients hospitalized for diarrhea. Transplantation 2011, 92, 61-69. [CrossRef] [PubMed]

237. Jiang, X.; Cubitt, W.D.; Berke, T.; Zhong, W.; Dai, X.; Nakata, S.; Pickering, L.K.; Matson, D.O. Sapporo-like human caliciviruses are genetically and antigenically diverse. Arch. Virol. 1997, 142, 1813-1827. [CrossRef] [PubMed]

238. Hansman, G.S.; Oka, T.; Sakon, N.; Takeda, N. Antigenic diversity of human sapoviruses. Emerg. Infect. Dis. 2007, 13, 1519-1525. [CrossRef] [PubMed]

239. Sánchez, G.J.; Mayta, H.; Pajuelo, M.J.; Neira, K.; Xiaofang, L.; Cabrera, L.; Ballard, S.B.; Crabtree, J.E.; Kelleher, D.; Cama, V.; et al. Epidemiology of Sapovirus Infections in a Birth Cohort in Peru. Clin. Infect. Dis. 2018, 66, 1858-1863. [CrossRef]

240. Liu, X.; Jahuira, H.; Gilman, R.H.; Alva, A.; Cabrera, L.; Okamoto, M.; Xu, H.; Windle, H.J.; Kelleher, D.; Varela, M.; et al. Etiological Role and Repeated Infections of Sapovirus among Children Aged Less than 2 Years in a Cohort Study in a Peri-urban Community of Peru. J. Clin. Microbiol. 2016, 54, 1598-1604. [CrossRef]

241. Miyazaki, N.; Taylor, D.W.; Hansman, G.S.; Murata, K. Antigenic and Cryo-Electron Microscopy Structure Analysis of a Chimeric Sapovirus Capsid. J. Virol. 2015, 90, 2664-2675. [CrossRef]

242. Chen, R.; Neill, J.D.; Noel, J.S.; Hutson, A.M.; Glass, R.I.; Estes, M.K.; Prasad, B.V. Inter- and intragenus structural variations in caliciviruses and their functional implications. J. Virol. 2004, 78, 6469-6479. [CrossRef] [PubMed]

243. Amin, M.R.; Siddiqui, M.S.; Ahmed, D.; Ahmed, F.; Hossain, A. B- and T-cell epitope mapping of human sapovirus capsid protein: An immunomics approach. Int. J. Bioinform. Res. Appl. 2011, 7, 287-298. [CrossRef] [PubMed]

244. Diez-Valcarce, M.; Castro, C.J.; Marine, R.L.; Halasa, N.; Mayta, H.; Saito, M.; Tsaknaridis, L.; Pan, C.Y.; Bucardo, F.; Becker-Dreps, S.; et al. Genetic diversity of human sapovirus across the Americas. J. Clin. Virol. Off. Publ. Pan. Am. Soc. Clin. Virol. 2018, 104, 65-72. [CrossRef]

245. Varela, M.F.; Rivadulla, E.; Lema, A.; Romalde, J.L. Human Sapovirus among Outpatients with Acute Gastroenteritis in Spain: A One-Year Study. Viruses 2019, 11, 144. [CrossRef] [PubMed]

246. Mann, P.; Pietsch, C.; Liebert, U.G. Genetic Diversity of Sapoviruses among Inpatients in Germany, 2008-2018. Viruses 2019, 11, 726. [CrossRef]

247. Baker, J.M.; Tate, J.E.; Leon, J.; Haber, M.J.; Pitzer, V.E.; Lopman, B.A. Postvaccination Serum Antirotavirus Immunoglobulin A as a Correlate of Protection Against Rotavirus Gastroenteritis Across Settings. J. Infect. Dis. 2020, 222, 309-318. [CrossRef]

248. Bernstein, D.I.; Ziegler, J.M.; Ward, R.L. Rotavirus fecal IgA antibody response in adults challenged with human rotavirus. J. Med. Virol. 1986, 20, 297-304. [CrossRef] 
249. Coulson, B.S.; Grimwood, K.; Masendycz, P.J.; Lund, J.S.; Mermelstein, N.; Bishop, R.F.; Barnes, G.L. Comparison of rotavirus immunoglobulin A coproconversion with other indices of rotavirus infection in a longitudinal study in childhood. J. Clin. Microbiol. 1990, 28, 1367-1374. [CrossRef]

250. Lappalainen, S.; Blazevic, V.; Malm, M.; Vesikari, T. Rotavirus vaccination and infection induce VP6-specific IgA responses. J. Med. Virol. 2017, 89, 239-245. [CrossRef]

251. Czakó, R.; Atmar, R.L.; Opekun, A.R.; Gilger, M.A.; Graham, D.Y.; Estes, M.K. Serum hemagglutination inhibition activity correlates with protection from gastroenteritis in persons infected with Norwalk virus. Clin. Vaccine Immunol. CVI 2012, 19, 284-287. [CrossRef] 